\title{
The Trouble with Identity and Progressive Origins in Defending Labour Law
}

Alvaro Santos

Georgetown University Law Center, asantos@law.georgetown.edu

This paper can be downloaded free of charge from:

https://scholarship.law.georgetown.edu/facpub/2247

https://ssrn.com/abstract=3553515

Alvaro Santos, The Trouble with Identity and Progressive Origins in Defending Labour Law, in Critical Legal Perspectives on Global Governance: Liber Amicorum David M. Trubek 207-246 (Gráinne de Búrca, Claire Kilpatrick \& Joanne Scott eds., Oxford: Hart Publishing 2014)

This open-access article is brought to you by the Georgetown Law Library. Posted with permission of the author. Follow this and additional works at: https://scholarship.law.georgetown.edu/facpub

Part of the International Law Commons, and the Labor and Employment Law Commons 


\title{
The Trouble with Identity and Progressive Origins in Defending Labour Law
}

\author{
Alvaro Santos*
}

Table of Contents

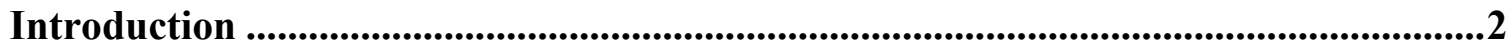

I. The Case of Mexico and Its Labour Regulation....................................................4

A. The Debate about Labour Law Reform In Mexico .................................................. 7

B. Workers' Rights: A National Invention? ...........................................................................13

i. Workers' Rights as the Result of the 1910 Mexican Revolution.................................... 13

ii. Workers' Rights as the Invention of Mexican Intellectuals and Legal Scholars ............ 14

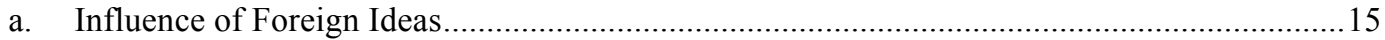

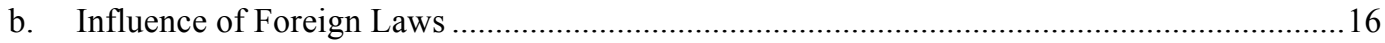

iii. Workers' Rights as a Creation of the 1917 Mexican Constitution ............................... 17

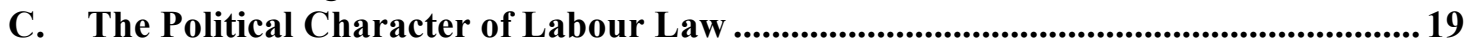

i. Labour Law as a Radical Political Project ...................................................................... 19

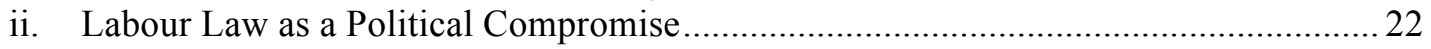

iii. A Typology of the Political Character of Social Law ................................................ 24

D. Explaining the Traditional Narrative ...............................................................................25

E. Implications of the Mexican Story for Debates in Other Countries ............................. 30

II. National Identity in Current Debates about Social Regulation in Europe .........31

A. The Use of Identity and the Push to Constitutionalize Social Rights ........................31

B. Identity as Resistance .......................................................................................................33

C. Identity to What Effect?........................................................................................................ 34

III. Labour Reform and Economic Development: Thinking About Potential Alternatives...........................................................................................................38

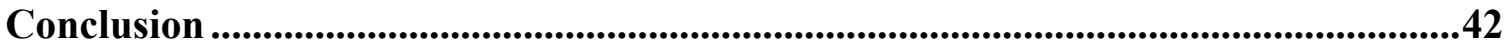

\footnotetext{
- Associate Professor of Law, Georgetown University Law Center. I would like to thank Harry Arthurs, Dennis Davis, Jorge Esquirol, Michael Fischl, Diego López-Medina, Alejandro Lorite, Naomi Mezey, David Kennedy, Duncan Kennedy, Nina Pillard, Kerry Rittich, Chantal Thomas, David Trubek, and Philomila Tsoukala for conversations and helpful comments on this project. Rachel Evans and Carolyn Cadena provided excellent research assistance. Forthcoming in GLOBAL GOVERNANCE: CRITICAL LEGAL PERSPECTIVES (Hart Publishing 2013).
} 
Just like France, after its Revolution, had the great honour of consecrating in the first of its Constitutions the immortal rights of men, so will the Mexican Revolution have the legitimate pride to show the world that it is the first one to consecrate in a Constitution the sacred rights of workers. ${ }^{1}$

(Alfonso Cravioto, Address to the 1916-17 Constitutional

Assembly)

\section{Introduction}

Debate about labour regulation is not new. What is new is the urgency with which labour law reform is promoted as an important fix to economic woes. In recent years, calls for reform resound in poor and rich countries alike. The economic crisis in the United States and in Europe has intensified these debates, making labour regulation a prime target for reform. In several US states public sector unions have been under attack, depicted as a privileged class that drains public funds with high wages, cosy benefits, and retirement privileges that no other workers enjoy. Several European countries have introduced austerity measures that target labour regulation and other foundations of the welfare state as sources of economic waste that they can no longer afford. Moreover, it is argued that "rigid" labour regulation hampers job creation, which can be strengthened through a program of labour flexibilisation.

On the other hand, there is considerable opposition to labour flexibility from labour activists and scholars who seek to defend the current structure. They regard today's job stability and benefits as historical achievements and fundamental rights. Defenders of labour regulation want to preserve workers' protections, which they see as the last line of defence against enormous pressure from global capital, and resist the flexibility rhetoric, which they see as the handmaiden of capital.

The dire situation of the labour movement worldwide is reflected in the crisis of labour law as an academic field. The field is in a state of soul-searching, with scholars attempting to determine how labour scholarship can grapple with the defeat of the traditional labour movement and with conditions in the global economy that make its recovery seem impossible. ${ }^{2}$

In this article, I examine two prominent arguments opponents of labour flexibility have used to defend labour regulation, that labour regulation: is closely associated with the nation's identity, and is inherently progressive. These arguments have been widely used in national debates in countries with strong traditions of social regulation and welfare state institutions. Resonances of these argument strands can also be seen in

\footnotetext{
${ }^{1}$ Diario de los Debates del Congreso Constituyente, 1916-1917 (Mexico, 1960).

2 See eg Davidov, Guy and Langille, Brian, eds, The Idea of Labour Law (Oxford University Press 2011).
} 
regional debates, such as the debate about "Social Europe" and the future of social regulation in the continent in light of further market economic integration.

This article focuses on the case of Mexico to show both these arguments' appeal and their downsides. Mexico proudly considers itself to be the first country to constitutionalize workers' rights and, for much of its modern life, has seen itself as a social state. In the 1980s, however, Mexico introduced an economic liberalization program that has had profound effects on its labour market and social security institutions. Liberal reformers characterize labour law as a key, pending structural reform to help the country get on a path to economic growth. Defenders of labour regulation see it as one of the last bastions against an economic model that has thus-far produced meagre growth and has increased social and economic inequality.

Challenging Mexico's historical narrative, I show how social law was, and still is, a truly transnational phenomenon, not necessarily associated with any one nation's identity. In addition, I examine how, even at the moment of its creation, social law was - and still is - politically indeterminate and, thus, its inherent association with progressive politics is unwarranted. Finally, I argue that the constitutionalization of social rights does not guarantee progressive results. These critiques are relevant to the current debate about labour regulation in Mexico, where political actors refer to the great achievements of the Constitution to defend existing regulation. This defence fails to engage critiques about the effects of social regulation on different groups of workers and on the economy in general. Social law advocates using these arguments are prone to idealizing existing social regulation, making it harder to consider potential alternatives. Ironically, neoliberal advocates for labour flexibility have begun to use social law to justify their agenda, reinforcing the assertion that social rights are politically indeterminate.

These insights from Mexico may be relevant to contemporary debates about social regulation elsewhere. In particular, I examine the strong parallels between Mexico and the debate about social regulation in Europe. In the European Union (EU), the project of market economic integration is said to have undermined workers' rights and social entitlements at the national level. Those seeking to advance similar social protections at the regional level have done so on identity terms, speaking of "Social Europe" as reflecting the continent's true self in need of institutionalization. These advocates have sought to constitutionalize social rights at the European level to ensure those protections. At the same time, those who regard further economic integration as a threat resist it on identity terms at the national level, seeking to preserve the social protections of the welfare state. Both regionally and nationally, resorting to social law is supposed to advance progressive aspirations and resist the unfettered march of the market. Relying on national -or regional- identity to justify social regulation, however, creates problems similar to Mexico: failing to engage arguments about the effects of social law and preventing the imagination of alternatives. At this moment of crisis for the euro zone, when the monetary union's viability is being tested, social law discourse has been employed by the EU even as it pursues an austerity agenda; this indicates that the political valence of this discourse is again in flux.

The article is divided in three parts. In the first part, I analyze the traditional narrative of labour law in Mexico and challenge its historical claims to national identity and 
progressive politics. I use the case of Mexico, the country that first enshrined workers' rights in a Constitution, as a paradigmatic example of both the appeal and the pitfalls of the social law position. I examine the insights that the critique of the traditional narrative may contribute to the current debate about labour law in Mexico. In the second part, I explore the caveats that the Mexican case may raise for debates about social regulation elsewhere, particularly in Europe. I analyze how identity arguments play an important role in the concept of "Social Europe" and the regulations or social provisions that are assumed to be inherent to the nature of the EU. I will also show how some European countries have used a national identity argument to defend their social regulation against what they perceived to be a threatening pro-market European Union integration program. In the third part, I examine what could be gained by abandoning identity-based arguments and, instead, analyzing labour reform as part of a country's overall development strategy.

\section{The Case of Mexico and Its Labour Regulation}

The reader might not know this, but the idea of social law and the constitutionalization of workers' rights originated in Mexico. Well, not quite. But that is, in a simplified way, the traditional narrative in Mexico's labour law scholarship. The idea of social law emerged as a critique of classical legal thought in the late nineteenth century and was developed by German and French jurists. These scholars challenged nineteenth-century classical legal liberalism's individualistic assumptions, critiqued its abuse of logical deduction and condemned its social and economic consequences. ${ }^{3}$

Social law jurists argued that individualistic classical liberal law was inadequate to deal with new, interdependent relations brought about by industrialization, urbanization, economic globalization and deep social changes of the late nineteenth-century. ${ }^{4}$ These scholars laid the foundations for and helped develop a new legal sphere called social law, doctrinally situated between traditional private law and public law, in which the State was an active participant. This new sphere introduced legal regimes we now associate with the regulatory state, such as labour legislation, social security, housing law, sanitary law and financial regulation. ${ }^{5}$ After World War I, there was also the rise of a new international law regime to deal with war that created new institutions based on the idea of interdependence. ${ }^{6}$

\footnotetext{
${ }^{3}$ See Kennedy, Duncan, Three Globalizations of Law and Legal Thought: 1850-2000, in Trubek, David \& Santos, Alvaro, eds, The New Law and Economic Development: A Critical Appraisal (Cambridge University Press 2006) 37-40; Gurvitch, Georges, Le Temps Présent et L'idée du Droit Social (Paris, J. Vrin 1932); Reimann, Mathias "Continental Imports - The Influence of European Law and Jurisprudence in the United States," (1996) 64 Tijdschrift Voor Rechtsgeschiedenis 391, 398-99.

${ }^{4}$ Kennedy, Three Globalizations 38.

${ }^{5}$ Kennedy, Three Globalizations 38-39.

${ }^{6}$ The International Labour Organization (ILO) was founded by the Treaty of Versailles in 1919 to deal with the "labour question," which was of increasing concern among Western powers and a potential source of international conflict. Constitution of the ILO, pmbl, June 28, 1919, 49 Stat. 2712, 2713-14, 225 Consol. T.S. 373 ("[C]onditions of labour exist involving such injustice hardship and privation to large numbers of people as to produce unrest so great that the peace and harmony of the world are imperilled."). The legal regime of labour law, which supersedes classical conceptions of property and contract, has conceptual parallels with a new international law regime that supersedes classical concepts of sovereignty. Both fields were influenced by social law ideas. This parallel is exemplified by the work of George Scelle, a French
} 
Social law is paradoxical. Although it spread globally from Germany and France to become a truly international phenomenon, it was understood as having a unique relation to the particular society of each country where it took hold. Social law was often considered grounded on some primordial, traditional or religious character of each society that claimed it. $^{7}$

Mexico provides a useful case study of the use of nationalism by social law advocates. Mexico prides itself on its social legal system, which emerged out of the 1910 revolution, was enshrined in the 1917 Constitution and has a self-image of being very progressive. The national identity justification of social law is not limited to labour regulation but, indeed, exists in other domains. Establishing a communal form of land ownership, in the form of "ejido," was justified as an explicit opposition to the liberal and individualistic property rights system and a return to pre-liberal and colonial forms of land-tenure. ${ }^{8}$ The defence of the legal regime of natural resources, such as oil and water, is also often justified on national identity terms.

When it comes to labour regulation, two main claims permeate the traditional narrative of Mexican labour law textbooks: first, that labour law is of Mexican origin and, second, that labour regulation is inherently progressive and helps all workers. Mexican labour law scholarship has helped shape and sustain the idea that social law stemmed from a unique Mexican reality - triggering the 1910 Mexican revolution - and that workers' rights were inserted in the 1917 Constitution thanks to the genius of Mexicans intellectuals, scholars and politicians. ${ }^{9}$ The fact that the 1917 Mexican Constitution was the first in the world to enshrine workers' rights has lent credibility to these claims. Mexican jurists argue that, just as France gave the world the first Declaration of the Rights of Men, Mexico gave the world the first Declaration of Social Rights. The inauguration of this social legal system within the 1917 Constitution has been closely associated with a progressive Mexican state. The native and progressive characteristics of the social state are so central to the state's identity that to challenge them is to question its foundational justifications. It amounts to unveiling the state's main foundational fictions. ${ }^{10}$

jurist who began as a labour scholar and later became a renowned international law scholar. See eg Scelle, Georges Le Droit Ouvrier: Tableau de la Législation Française Actuelle (Paris, Armand Colin 1932); Scelle, Georges, Manuel Élémentaire de Droit International Public (Paris, Domat-Montchrestien 1943).

${ }^{7}$ Kennedy, Three Globalizations at 46-50; see eg, Shalakany, Amr Sanhuri and the Historical Origins of Comparative Law in the Arab World, in Riles, Annelise, ed, Rethinking the Masters of Comparative Law 152 (Portland, Hart Publishing 2001) (justifying the civil code socialisation by Sanhouri in Egypt as grounded on Islamic tradition); Kan'gara, Sylvia, “Analytical, Prescriptive and Resistant Characterizations of 'African' Conceptions of Property: A Critique of Mainstream Assumptions about African-Western Incompatibility" (SJD Dissertation, Harvard Law School 2003) (how the social function of property in Africa was justified using indigenous notions).

${ }^{8}$ See Nuñez Luna, Alejandra, "Water Law and the Making of the Mexican State, 1875-1917" (SJD Dissertation, Harvard Law School 2011); Simpson, Eyler N., The Ejido? Mexico's Way Out (Chapel Hill, UNC Press 1937).

${ }^{9}$ See eg Noriega Cantú, Alfonso, Los Derechos Sociales, Creación de la Revolución de 1910 y de la Constitución de 1917 (Mexico, Universidad Nacional Autónoma de México 1988).

${ }^{10}$ I borrow the term "foundational fictions" from Doris Sommer, who argued that the late nineteenth and early twentieth-century novels in Latin America intended to foster a "passionate patriotism" in the new 
One way to think about the traditional labour law narrative is that Mexico has an originalist constitutional tradition that is progressive and associated with the left. Think of the work of Frank Michelman and William Forbath, depicting a social tradition in the US, wherein welfare rights (work, housing, health) can be based on the constitution. ${ }^{11}$ Now imagine this stance represents the mainstream position.

This section analyzes the mainstream labour law scholarship in Mexico. I focus particularly on the work of Mario de la Cueva, the foremost labour law scholar and one of the main architects in constructing the legal foundation for the social state. He imagined, argued and worked for the reconstruction of the Mexican legal system around social law. ${ }^{12}$ I suggest that De la Cueva is to the Mexican twentieth century legal system what Diego Rivera is to Mexican art - not because of equal fame or notoriety, but because they shared a passion and a vision about the new social order, and created an aesthetic and legal narrative to support it. Rivera heralds the post-Revolution Mexican state as the modern response to colonialism and economic exploitation. Rivera's murals are an elegy to the new man, the worker, emancipated from his past chains. De la Cueva paints the legal regime that would ensure workers' liberation.

Rivera depicts the country in a path of industrialization, where nineteenth century bourgeois capitalism, the old economic regime against which the revolution rebelled, is superseded by a socialist state. The character of that social state is still not fully defined, but it becomes clear early on that it is not a communist state. De la Cueva's murals are his major Mexican Labour Law textbooks, which create, document and justify this story in legal theory and doctrine. Describing the creation of Mexican labour law, De la Cueva tells us:

Mexican labour law is a statute imposed by life, a cry by men that only knew of exploitation and ignored the meaning of the term: my rights as a human being. It was born in the first social revolution of the 20th century and found its most beautiful historic crystallization in the 1917 Constitution. Before those years there were efforts in defence of men, actions were undertaken and ideas presented, but a regime that gave back to work its liberty and dignity had not been achieved; they were lost in the centuries of slavery, of servitude and of the bourgeoisie's private law. The idea that has now reached a universal character had not been declared:

nations. See Sommer, Doris, Foundational Fictions: The National Romances of Latin America (University of California Press 1991).

${ }^{11}$ See eg Michelman, Frank, "The Supreme Court, 1968 Term — Foreword: On Protecting the Poor through the Fourteenth Amendment" (1969) 83 Harvard L. Rev. 7 (arguing equality of opportunity is consistent with the Equal Protection Clause of the United States Constitution); Michelman, Frank, "In Pursuit of Constitutional Welfare Rights: One View of Rawls' Theory of Justice” (1973) 121 U. PA. L. Rev. 962 (discussing John Rawls' theory of inherent welfare rights based on the tradition of "western individualistic democratic liberalism"); Forbath, William, "The Distributive Constitution and Workers' Rights" (2011) 72 Ohio State Law Journal 1115 (depicting the history and significance of labour and workers rights as fundamental rights).

${ }^{12}$ De la Cueva, Mario, El Nuevo Derecho del Trabajo, 13th edn (Mexico, Editorial Porrúa 1993). 
labour law constitutes the new rights of the human person, the base without which the old rights of men are not possible. ${ }^{13}$

This section problematizes this traditional narrative, most articulately formulated by De la Cueva. I argue first that the critique to nineteenth century private law and the proposal for social law as a way to overcome the doctrinal limitations and undesirable economic consequences of legal liberalism was not purely Mexican in origin. Second, I claim that the nature of the political compromise that enabled the constitutionalisation of labour rights and the creation of new social law institutions was less radical at its inception, and less progressive as applied, than is commonly portrayed.

Before subjecting the traditional narrative to scrutiny, however, I will describe its relevance in the current labour reform debates. Political parties, activists and scholars refer to the achievements of the Constitution and the historically progressive character of labour legislation to buttress their positions. Exploring the grip this narrative has on the way actors think and talk about labour regulation clarifies the relevance of its critique and the possibilities that may open if we go beyond it.

\section{A. The Debate about Labour Law Reform In Mexico}

Labour law reform has been the subject of political debate for the last 22 years, since liberalization reforms were introduced in the country by the Salinas administration between 1988-1994. In this protracted debate, the achievements of the Revolution and the historical legacy of the Mexican constitution play an important, if not always explicit, role. The nationalist discourse that emerged after the Mexican revolution, created and consolidated during seven decades of a one-state-party system in which the Institutional Revolutionary Party (PRI) ruled, praised constitutionally protected workers' rights and labour legislation as a historical achievement. This legislation was considered a key pillar of the country's modern social, economic and political life. Today, more than two decades after the introduction of economic liberalization policies, labour law reform is considered a "pending" structural reform and is once again at the centre of political debate. Since 1990, multiple proposals have been introduced, including bills by the three main political parties: the centre-right National Action Party (PAN), which has ruled the country since 2000, the leftist Democratic Revolution Party (PRD) and, in 2011, the PRI. After the 2012 presidential elections and with a newly-elected congress, outgoingPresident Calderón introduced a labour bill that this time congress will be required to vote on. ${ }^{14}$

The Constitution and federal labour law grant substantial protections to workers. They took employment relations out of the civil law domain and created the country's social security system. In 1917, Article 123 enshrined workers rights in the Mexican

\footnotetext{
${ }^{13}$ De la Cueva, Nuevo Derecho, vol 1, 38 (emphasis in original).

${ }^{14}$ Proyecto Decreto que Reforma, Adiciona y Deroga Diversas Disposiciones de la Ley Federal del Trabajo, LXII Legislature (1 September 2012) www.stps.gob.mx/bp/secciones/sala_prensa/Ini_Ref_Laboral_2012.pdf.
} 
Constitution and granted workers considerable protections. ${ }^{15}$ Based on these constitutional rights, the federal labour law regulates the labour market in great detail, dealing with both individual and collective employment relations. Article 123 seeks to establish an equilibrium between workers and employers, and to advance social justice. ${ }^{16}$ It stipulates that labour is not an article of commerce; it should safeguard workers' freedom and dignity and guarantee a decent standard of living. ${ }^{17}$ Importantly, federal labour law's procedural section is guided by a default rule that stipulates that whenever there is doubt in the interpretation of the law, the Conciliation and Arbitral Board will choose the one that favours workers. ${ }^{18}$ The Board is also required to supplement workers' briefs when failing to request benefits they are entitled to. ${ }^{19}$

Despite these generous protections, Mexico's labour market is in dire straits. The working population totals approximately 50 million people. ${ }^{20}$ Every year, one million youths become economically active and ready to enter the labour market; the country's economy has been able to create only half of those jobs. ${ }^{21}$ People migrate to the US to find jobs, but many enter the informal economy by working on petty street commerce or enter the ranks of drug cartels or other criminal organizations. ${ }^{22}$ Unemployment is approximately 5.4 per cent, but this number does not capture a significant number of workers: the approximately 8.3 per cent who are underemployed. ${ }^{23}$ Of the employed, a great number have very precarious jobs, with meagre wages and no benefits. In fact, real

\footnotetext{
${ }^{15}$ Article 123 includes the following requirements and provisions: eight-hour maximum workday; minimum one day off per week; double payment for over-time work; prohibition on child labour; paid maternity leave; right to equal pay for equal work regardless of gender; establishment of a minimum, living wage; wage protection against discounts or reductions for debt obligations; establishment of employers' liability for workplace accidents and illnesses; establishment of workers' right to a share in the firm's profits; employers must comply with health and safety regulations; housing requirements for certain sectors; recognized the right to unionize and the right to strike; employers cannot dismiss workers without cause; and establishing of a tri-partite arbitral and conciliation boards to solve disputes between capital and labour, staffed by government representatives, employers and workers. Political Constitution of the United Mexican States (hereinafter "Mexican Constitution”), Art. 123 (1917).

${ }^{16}$ Federal Labour Law of Mexico (Ley Federal de Trabajo) Art. 2.

${ }^{17}$ Idem 3.

${ }^{18}$ Idem 18.

${ }^{19}$ Idem 685

${ }^{20}$ Instituto Nacional de Estadística y Geografía (INEGI), Indicadores Oportunos de Ocupación Y Empleo ["Job Indicators"] (2012) www.inegi.org.mx/inegi/contenidos/espanol/prensa/comunicados/ocupbol.pdf. ${ }^{21}$ Zepeda, Eduardo; Wise, Timothy, and Gallagher, Kevin, Rethinking Trade Policy for Development: Lessons From Mexico Under NAFTA (Carnegie Endowment for International Peace (Washington, D.C., Carnegie Endowment 2009); Kurtzman, Joel, “Mexico's Job-Creation Problem,” WSJ, 3 August 2007, online.wsj.com/article/SB1 18610985048187068 .html.

${ }^{22}$ From 1990 to 2010, approximately 8.9 million Mexicans migrated to the United States. A recent report, however, found that migration declined significantly in the last five years. Pew Hispanic Center, "The Mexican-American Boom: Births Overtake Immigration" at 3 (2011) www.pewhispanic.org/files/reports/144.pdf. Possible explanations include increased unemployment and greater deportations in the US and a spike of violence in the border area, decreasing birth rates and broader economic opportunities in Mexico. Pew Hispanic Center, "Net Migration from Mexico Falls to Zero-and Perhaps Less" (2012) www.pewhispanic.org/files/2012/04/Mexican-migrants-report_final.pdf

${ }^{23}$ INEGI, Job Indicators 2011, www.inegi.org.mx/inegi/contenidos/espanol/prensa/comunicados/ocupbol.asp.
} 
minimum wages have declined dramatically in the last four decades. ${ }^{24}$ This suggests that even in the formal economy there is a wide de facto flexibility in the labour market due to low wages, informal or illegal part-time contracting by employers, outsourcing and the non-provision of legally-mandated benefits. This further suggests that a considerable part of the productivity gains in recent years have relied on decreased labour costs. Consequently, the share of productivity gains to labour in general terms has decreased. ${ }^{25}$

Now consider the reform proposals advanced by the main political parties. Over the past twelve years, each of the two government administrations headed by the PAN has introduced a labour law bill. These bills proposed making labour market regulation more flexible by creating new part-time, trial and training employment contracts. They also proposed changes to collective bargaining rules that would make it harder for workers to strike, prohibit closed-shop agreements and stop automatic withholding of union fees by the employer. The PAN also proposes to introduce transparency and union democracy by requiring free and secret elections (for strikes, control over collective agreements and union leadership), imposing the obligation for unions to publish their balance sheets and make them available to members, and requiring the publication of unions' registration, collective agreements and firms' internal workplace regulations.

Opposition to the PAN bills has come from different sectors. These include the leftist PRD, unions, activists, NGOs and labour law scholars. Many have emphasized the bill's violation of fundamental workers' rights recognized not only in the Mexican constitution but also in international conventions. In their view, the PAN bill sought to introduce the neoliberal flexibility agenda, which jeopardized fundamental workers' rights and threatened to impoverish workers and weaken unions. Activists referred to the conquests of the Mexican Revolution and the achievements of the Constitution as a way to resist the neoliberal program, often portrayed as an import of an economic agenda designed abroad and supported by employers, foreign economic interests and international financial institutions. In addition, a number of independent unions and NGOs brought a complaint before the NAFTA's National Administrative Office, claiming the bill violated NAFTA's labour side agreement. ${ }^{26}$ Faced with the PAN's bills, many groups on the left have preferred the status quo.

\footnotetext{
24 "The real minimum wages in 2000 represented only a third of those of 1980; national wages in 2000 were equivalent to 50 per cent of those of 1980. By 2000, wages and salaries in large manufacturing plants had dropped to less than 40 per cent of their level in 1990." Salas, Carlos and Zepeda, Eduardo, Empleo y Salarios en el Mexico Contemporáneo, in La Situacion del Trabajo en Mexico 37, 55 (México, Instituto de Estudios del Trabajo 2003); Fairris, David, Popli, Gurleen and Zepeda, Eduardo, "Minimum Wages and the Wage Structure in Mexico" (University of California Riverside, July 2005),

http://economics.ucr.edu/papers/papers05/05-09.pdf, 4, 23, 28; Zepeda, Rethinking Trade Policy 13-14.

${ }_{25}$ Enrique Hernández Laos, La productividad en Mexico: Origen y Distribución 1960-2002, in Salas, Carlos, ed, La Nueva, Situación del Trabajo en Mexico 2000-2003 (Mexico City, Instituto de Estudio del Trabajo, 2006) 161, 168-69 (although productivity has remained low in Mexico from 1988-2002, workers transferred much of their productivity gains to employers); see also Polanski, Sandra Mexican Employment, Productivity, and Income a Decade After NAFTA, www.carnegieendowment.org/pdf/files/canadasenatebrief.pdf (Carnegie Endowment 2004).

${ }^{26}$ See U.S. NAO Public Submission US2005-01 from the Washington Office on Latin America, to U.S. Dep't of Labor, Bureau of Int'1 Labor Affairs (Feb. 17, 2005) www.dol.gov/ilab/media/reports/nao/submissions/Sub2005-01.htm (requesting that the U.S. National
} 
On the left, the PRD and the Workers' National Union (UNT), an association of independent unions, have proposed a bill that seeks to ensure stable and decent jobs in a manner that could be consistent with productivity gains, to dismantle corporatist institutions that benefit official unions and stifle union democracy, and to reform the dispute settlement system. ${ }^{27}$ The PRD-UNT bill accepts some degree of flexibility introducing, for instance, a limited version of the trial employment contract, but rejects other flexibility modalities, including the formalization of outsourcing, proposed by the PAN and PRI. The bill emphasizes that decisions on how to deploy labour to ensure productivity, including training and promotion, must be taken bilaterally. ${ }^{28}$ It also proposes to index wages to inflation to avoid further decline in real wages. ${ }^{29}$ On collective bargaining institutions, the PRD-UNT bill proposes the creation of an autonomous Public Registry, in charge of registering new unions and ownership over collective bargaining agreements, taking that role away from the Ministry of Labour. It keeps current rules that seek to resolve collective action problems. For instance, it partially keeps the closed shop agreement, requiring workers to become union members when they are hired - if the union and the employer have so agreed-but eliminates the closed shop by exclusion, enabling workers to exit the union without being fired. It also keeps rules that require employers to retain union fees. Finally, on administration of justice, the bill would eliminate the long-standing tripartite Conciliation and Arbitration Boards and replace them with labour courts, staffed by independent judges under the jurisdiction of the judiciary. ${ }^{30}$

The PRI, which had opposed the labour law reform proposals made by this and the previous PAN administrations and the PRD, introduced its own bill in $2011 .^{31}$ The PRI's bill introduces significant forms of flexibility, leaves collective bargaining institutions largely untouched, and preserves the current dispute settlement system. First, it proposes a series of changes to the standard employment contract by introducing flexibility in hiring and firing. ${ }^{32}$ It also seeks to formalize and regulate outsourcing, an extended

Administrative Office work with the Mexican government to eliminate alleged NAALC violations in the labor law reform proposal).

${ }^{27}$ Gaceta Parlamentaria, Cámara de Diputados, número 2989-IV (15 April 2010)

www.derechoasaber.org/data/arch_segui/_i200410-4.doc.

${ }^{28}$ The bill requires firms to regularly send financial status reports to its workers. Art 116. It also introduces some flexibility while also preventing the precarisation of jobs via low wages, unstable jobs and scarce benefits. Pmbl. The bill recognizes the importance of performance-based promotion rather than seniority, as well as the importance to train workers for multiple tasks. See eg Art 353-Z 19. It proposes that these decisions are taken bilaterally and based on productivity benchmarks. See Art 84. To ensure that goal, it proposes the creation of a firm-level Commission for Wages, Training and Productivity. Ch 2.

${ }^{29}$ It proposes eliminating the current Minimum Wage Commission, a tripartite organization composed by representatives of government, employers and official unions. Instead, the bill creates the National Commission for Wages, Training and Productivity, dependent on Congress and not on the Executive. Ch 2. ${ }^{30}$ PRD proposes to eliminate the distinction between Section A and Section B of Article 123, regulating private and public sector employment in the same way. Pmbl. This would grant public sector workers collective bargaining rights that they currently lack, primarily the right to strike.

${ }^{31}$ Propuesta que reforma, adiciona y deroga diversas disposiciones de la Ley Federal del Trabajo ("PRI bill”), Gaceta Parlamentaria Número 3218-II (2011).

32 The bill introduces hourly wages and multiple forms of new contract terms that would enable widespread use of part-time, fixed-term, and trial employment. PRI bill 32; 40. 
employer practice that is currently illegal. ${ }^{33}$ The government would remain in control of union registration and certification of elections and ownership of collective agreements. ${ }^{34}$ It consolidates the conciliation and arbitration boards but leaves them as tripartite bodies largely dependent on the executive power. Thus, it seems that the PRI bill seeks to compromise between two of its traditional constituencies: On the one hand, the bill seeks to satisfy employers who demand greater forms of flexibility in hiring and firing, limits to back wages payments for unfair dismissal and greater control over the allocation of labour to multiple tasks and over promotion. On the other hand, the bill seeks to guarantee that traditional corporatist unions will continue to enjoy a great degree of control over collective bargaining institutions, keeping independent unions at bay. The government would continue to have considerable say in the unions' governance system, keeping decisions of registration, confirmation of leadership and collective agreement control in the Ministry of Labour.

After twelve years as the opposition, the PRI won the 2012 presidential election and will soon be back in power. As the party that controlled the presidency and pretty much all branches of government for more than seven decades - and as the creator of the national revolutionary discourse - the PRI's bill is indicative of the debate to come and the upcoming government's agenda. In its preamble, the PRI bill makes several references to the historical achievement of the 1917 Constitution in enshrining workers' rights:

The 1917 Constitution created Article 123, which for the first time in history elevated labour law to the highest normative level. This was a fundamental decision, bedrock of the modern State that has received utmost recognition in the world. ${ }^{35}$

At every point, the bill declares that the proposed changes are necessary to improve the country's economic condition but are consistent with the historical achievements of the Constitution and respect workers' fundamental rights:

It is necessary to generate confidence in a private and international investment that creates jobs in the formal economy while observing the basic values of Article 123 and the basic rights of workers ... These rights must be well protected, as they have been since our first federal labour legislation from 1931, and as they should be, being an example for all social legislations in the world. ${ }^{36}$

The PRI revives the national revolutionary discourse to reach a compromise between supportive capital and official labour. It is not surprising that the bill preserves the privileges of the big labour unions traditionally affiliated to the PRI. However, the malleability of the social law discourse is significant: the PRI resorts to social law discourse to introduce a labour flexibility agenda, dear to business actors, that is anathema to many of the labour protections associated with the social position. It does so

\footnotetext{
${ }^{33}$ PRI bill 24.

${ }^{34}$ Ibid 23.

${ }^{35}$ Ibid at 20.

${ }^{36}$ Ibid 21.
} 
by appealing to national pride and vowing continuity with the very constitutional principles that the bill purports to modify. ${ }^{37}$

The stakes of labour reform are high. At bottom lie different visions of how to best increase firm productivity, the relationship between labour and capital, the state's involvement in unions' governance system, collective bargaining and dispute settlement. These different visions have diametrically different implications for the distribution of power and resources between capital and labour, and for democracy in the workplace. Beyond the particular rules supported by the political parties, I am interested in a common theme in these bills that evokes the historical achievement of the Mexican Constitution. This trope is used both by those who want to oppose the neoliberal flexibility program and those who want to preserve the corporativist regime currently in place.

It is hard not to wonder why social law rhetoric, particularly concerning the constitutionalisation of social rights, is so powerful in Mexico. Why does this alleged historical achievement remain so appealing in contemporary debates? It would be useful to investigate why it exerts so much influence: How it is that it still strikes a cord that seems to go to the very sense of selfhood of the nation? Or, conversely, if nobody believes in it any longer, if the once-faithful citizens have lost their faith, why do the dogmas of such national faith need to be invoked de rigueur in the debate? Is this just a simulation, a currency political actors have to use in the public space, a faith they disbelieve in private but nonetheless profess in public? Whether this professed faith is the expression of an honest belief or a cynical position, it seems worth examining what lies behind this historical assumption. Subjecting this claim to critical scrutiny can shed light on what is at stake in the "practice" of subscribing to it and reinforcing its validity.

In the following section, I will examine Mexico's traditional labour law narrative, outlining its main claims and probing why it has such as grip on the way people think about Mexico's history and its future. As I will show, legal scholars played a very important role in weaving a discourse about "social law" that would become closely associated to the nation's character. Legal scholars' reconstruction of the legal system around the idea of social law, crystallized in the 1917 Constitution, would also be the reconstruction of the nation's self for much part of the twentieth century.

\footnotetext{
${ }^{37}$ As soon as Congress began its session in September 2012, outgoing president Calderón proposed a new labour bill that, under a recently adopted legislative rule, requires Congress to vote the bill up or down within sixty days. This bill is very similar to previous PAN bills and is an attempt by the government to leave office with a badge of passing a much-touted "structural" reform. The bill was met with resistance by the left and provoked massive street demonstrations. The PRI, which now controls the House of Representatives, approved flexibility reforms to the employment contract but eliminated all proposals to democratize the union governance system. Thus, the PRI has achieved the same compromise between flexibility and corporatism it was seeking in its own bill. The PAN seemed willing to forego its union democracy proposals to achieve a labour reform and joined forces with PRI. After a heated debate and a few amendments the bill was finally passed. Senate of Mexico, LXII Legislature, BOLETÍN-0481 "Avala Senado Reforma Laboral y Envía al Ejecutivo los Artículos Aprobados Por Ambas Cámaras.” 13 November 2012.
} 


\section{B. Workers' Rights: A National Invention?}

Mexican legal scholars emphasize the national invention of social and workers' rights, and consider Mexico's 1917 Constitution to be a significant contribution to the world's jurisprudential history as the first "Declaration of Social Rights." I have identified three main claims: (1) social and workers' rights are the result of the 1910 Mexican revolution and, thus, a response to Mexican socioeconomic reality; (2) workers' rights are the invention of Mexican actors, be they intellectuals, revolutionary leaders, legal scholars, or politicians; and (3) workers' rights are the product of the 1917 Constitution and resulted from that historical constitutional debate.

These claims are prevalent in the traditional narrative of Mexican labour law scholarship. Affirmed by the canonical texts in the field and passed on to every generation of law students, there seems to be a strong interest in reinforcing the Mexican contribution to the origin of workers' rights and, more broadly, social rights. In this section, I explore these claims and, given the difficulty in sustaining this assumption, I begin to explore what may be the reasons for maintaining a nationalistic narrative.

\section{i. Workers' Rights as the Result of the 1910 Mexican Revolution}

Traditional labour law scholarship considers the creation of workers' rights and of social rights in general to be an achievement of the 1910 revolution. ${ }^{38}$ According to this view, the revolution was a response to the oppressive social and economic conditions under which workers and peasants lived during the long dictatorship of Porfirio Diaz. This socioeconomic reality inspired the development of workers' rights and labour law. According to De la Cueva, the 1917 Mexican Constitution is itself the first Declaration of Social Rights. ${ }^{39}$ De la Cueva asserts that this Declaration "stemmed from the tragedy and suffering of the people, and it was a natural, genuine, and authentic creation of the Mexican people, of the men who offered their life in the war of the revolution." ${ }^{40}$

The connection between the 1910 Mexican Revolution and the enactment of workers' rights is not as straightforward as the traditional narrative assumes. "Social" legislation existed before the armed movement. De la Cueva himself references labour legislation in Mexico preceding the revolution. For instance, in the last decade of the dictatorial regime of Porfirio Diaz from 1900 to 1910, two Mexican states enacted pro-worker statutes: In 1904, the State of Mexico enacted a workers' compensation law for injuries caused by workplace accidents, making employers liable for health care costs and full salary for up

\footnotetext{
${ }^{38}$ The Mexican revolution started in 1910 and lasted for a decade. For a comprehensive treatment of the Mexican Revolution see Knight, Alan, The Mexican Revolution, Vol 1: Porfirians, Liberals, and Peasants (University of Nebraska Press 1990) and Knight, Alan, The Mexican Revolution, Volume 2: Counterrevolution and Reconstruction (University of Nebraska Press 1990). See also Womack, John Zapata and the Mexican Revolution (Vintage 1970).

${ }^{39}$ De la Cueva, Nuevo Derecho 44.

${ }^{40}$ Ibid.
} 
to three months. ${ }^{41}$ In 1906 , the state of Nuevo León also enacted a law for workplace accidents. ${ }^{42}$

Furthermore, according to De la Cueva, during the interventionist government of Maximiliano of Habsburg -an Austrian prince imposed by the French government at the behest and with the collaboration of conservative groups in Mexico- Maximiliano enacted Mexico's first labour law, the "Labour Law of the Empire" (1865). ${ }^{43}$ As De la Cueva points out, this law contained some of the workers' benefits later enshrined in the 1917 Constitution. ${ }^{44}$ It is telling that so many years before the Mexican revolution, Maximiliano, a European prince arguably detached from the Mexican reality, had implemented pro-worker legislation. ${ }^{45}$ However, De la Cueva does not seem to give much importance to these historical precedents.

Examples in De la Cueva's books suggest that labour laws were enacted before the 1910 Revolution in at least two states. In fact, a foreign ruler had introduced pro-worker legislation as early as the mid-nineteenth century. This evidence weakens the assumption that only the revolution's unique context had influenced the content of the 1917 Constitution. In fact, existing legal doctrines and ideas about social law originating in Europe and circulating worldwide also seem to have provided ammunition in the passing of this legislation. As I will discuss below, the revolution may have accelerated the enactment of labour laws by different states throughout the country, and it may have given a justification to the members of the Constitutional Assembly to enshrine workers' rights in the Constitution, but the revolution cannot be considered the sole determinant.

\section{ii. Workers' Rights as the Invention of Mexican Intellectuals and Legal Scholars}

Another important argument in labour law scholarship posits that the intellectual origin of workers' rights in the country is entirely Mexican. Additionally, scholars argue that the various labour laws enacted in the country after the Revolution were entirely a domestic development and were not influenced by foreign laws. However, at the time, important ideas promoting the need to establish workers' rights were fermenting in the public debate transnationally. As I will show, some of the main intellectuals and legislators promoting the recognition of workers' rights were participants in a transnational movement for labour rights and were influenced by social law discussions going on in other countries.

\footnotetext{
${ }^{41}$ Ibid 43.

42 Ibid.

${ }^{43}$ Ibid 41 .

44 Ibid.

${ }^{45}$ This may be viewed as an early attempt to import into Mexico some of the legal doctrinal developments and legislation in Europe at the time.
} 


\section{a. Influence of Foreign Ideas}

In his book, Social Rights, A Creation of the 1910 Revolution and of the 1917 Constitution, ${ }^{46}$ Alfonso Noriega Cantú, an influential Mexican legal scholar, attributed the origin of social rights to the Mexican Revolution and the Mexican Constitution. He explicitly addressed the question of whether the 1910 Mexican Revolution was inspired or influenced by Marx's ideas and those of other critics of the capitalist system. ${ }^{47}$ Noriega contended that foreign theories had "no influence whatsoever" on the actors of the Revolution or those who wrote the Constitution and concluded that the 1910 Revolution "formed its ideological content inspired in the Mexican historical reality.",

In the course of arguing about the indigeneity of the 1910 revolution, Noriega identifies several Mexican intellectuals who promoted the creation of social rights in the period before the Revolution. ${ }^{49}$ These were the great critics of Porfirio Diaz's dictatorship whose critiques were expressed in the Program of the Liberal Party of 1906 and Flores Magón's newspaper Regeneración, among other sources. ${ }^{50}$ These ideas were articulated in the two most influential Manifestos of the Revolution, the Plan de San Luis and Plan de Ayala, issued by revolutionary leaders Ignacio I. Madero and Emiliano Zapata, respectively. ${ }^{51}$ Unfortunately, Noriega neglected to investigate the intellectual background of the Mexican critics he refers to, especially of the most central among them, Ricardo Flores Magón.

Consider Ricardo Flores Magón, who Noriega and most labour law scholars recognize as an intellectual influence of the Revolution ${ }^{52}$ and of labour law legislation. ${ }^{53}$ Noriega failed to inquire into Flores Magón's background and did not notice that he was a participant in a transnational intellectual and political movement critiquing economic liberalism and promoting "social law" ideas. Flores Magón's publications, along with a variety of biographies, highlight the influence of European and US thinkers on his liberal and anarchist political theories. ${ }^{54}$ That Flores Magón was influenced by and was himself in conversation with foreign ideas and intellectuals does not diminish his intellectual

\footnotetext{
${ }^{46}$ Noriega Cantú, Derechos sociales 83.

47 Ibid.

48 Ibid.

${ }^{49}$ Noriega Cantú, Derechos Sociales 83.

${ }^{50}$ Noriega Cantú, Derechos Sociales 83.

51 Ibid.

52 De la Cueva also maintains that the 1906 Manifesto of the Liberal Party, which Flores Magón presided, is "the most important pre-revolutionary document in favor of the creation of a labour law. De la Cueva Nuevo Derecho 42.

${ }^{53}$ Nestor De Buen - perhaps the most prominent labour law scholar in Mexico today - argues that Flores Magón's influence over some leaders eventually translated into specific legislation as the leaders seized power in a variety of states. De Buen, Nestor, Derecho del Trabajo, 2nd edn vol 1 (Mexico, Editorial Porrúa 2010) 334. De Buen notes that for instance, General Manuel M. Dieguez, one of the leaders of the strike of Cananea (1906), in which Flores Magón was greatly involved, later enacted a labour law for the state of Jalisco (1914). Ibid 330.

${ }^{54}$ See Crockroft, James, Intellecutal Precurosors of the Mexican Revolution 1900-1913 (Austin, University of Texas Press 1968) 117-133; García Cantú, Gastón, El Socialismo en Mexico. Siglo XIX, 1st edn (Mexico, ERA 1969) 120-29.
} 
stature or originality. It does, however, cast doubt on the assertion that social rights ideas, even those promoted by Flores Magón, were homegrown.

The Catholic Social Doctrine was an additional intellectual source in the creation of social law. The influence of social Catholicism in Mexico can be traced to the second half of nineteenth century. ${ }^{55}$ Labour scholars have recognized the importance of this doctrine in labour law in general, and in the Mexican labour regime in particular. ${ }^{56}$ Notably, Pope Leon XIII's Rerum Novarum advocated for the reconciliation of social classes, affirming that "without work there can be no capital, neither can be work without capital.",57 Among its main postulates, the encyclical included respect for private property, conciliation of classes, mutual cooperation for capitalist production and workers' welfare and unionization to assure decent living conditions. ${ }^{58}$ If these ideas had an impact in the creation of labour legislation, it would be evidence of yet additional influence of foreign ideas in the Mexican intellectual and political milieu that resulted in the protection of workers' rights.

\section{b. Influence of Foreign Laws}

Just as there is a tendency to deny the influence of foreign ideas in the creation of workers' rights in Mexico, there is also a tendency to deny the influence of foreign laws in the local labour legislations that followed the 1910 Revolution. De la Cueva, for instance, notes that the 1918 Labour Law of the State of Veracruz - the first State statute enacted after the promulgation of the Constitution - emphasized the statute's national character in its preamble. ${ }^{59}$

"[I]t was a permanent criterion to create a law, that was above anything else, Mexican ... that was a product of our environment, a legitimate daughter of our Revolution and of our fundamental laws, that faithfully responded to our needs. ... We did not want to fill the law with translations or copies of foreign laws, even if wise; we did not want to include any precept for the sake of an elegant or precise form which was formulated by legislators of other countries; we fundamentally wanted to guarantee the application of the law to our environment, to our social and political conditions, to our present situation. $^{60}$

For De la Cueva, this was consistent with Mexican labour law's origin, which was "born in the fields and from revolutionary men, and which is not and has never been an extra logical imitation of other peoples' norms." ${ }^{\prime 61}$ According to De la Cueva, Veracruz's statute would greatly influence the first federal labour law (1931). The assertion of

\footnotetext{
${ }^{55}$ García Cantú refers to the activism of Plotino C. Rhodakanaty and his association called "La Social." See ibid 172-179.

${ }^{56}$ De Buen, Derecho del Trabajo 191-93, Noriega Cantu, Derechos Sociales 7; Garcia Cantu, El Socialismo en Mexico 172-795.

${ }^{57}$ De Buen, Derecho del Trabajo 192.

${ }^{58}$ De Buen, Derecho del Trabajo 192-193.

${ }^{59}$ De la Cueva, Nuevo Derecho.

${ }^{60}$ Ibid.

${ }^{61}$ Ibid 51.
} 
national origin, however, is in tension with a previous acknowledgment. De la Cueva had already pointed out that the 1904 and 1906 state laws were greatly inspired by the French Law of $1898 .^{62}$ In fact, by 1918 Congress considered it preferable to enact specific laws to address each of the various aspects of labour relations rather than a single code. ${ }^{63}$ According to De la Cueva, this position explains the two draft laws for "workplace accidents," "one of which ... was preceded by an excellent exposition of the theory of professional risk." legal development. The importation of this theory into this draft project, and finally to the 1931 federal law, seems clear.

\section{iii. Workers' Rights as a Creation of the 1917 Mexican Constitution}

There is no stronger claim about the Mexican provenance of workers' rights than the proposition that Mexico's 1917 Constitution was the first in the world to enshrine such rights. Labour law textbooks commonly cite Mexico as the "first country to enact social rights in a constitution." 65

Based on this temporal advantage, Mexican scholars often argue that the Mexican Constitution created the concept of social rights, and that such rights were Mexicans' direct response to their country's reality. ${ }^{66}$ My interest in this section is not to debate the temporal priority of the Mexican Constitution in the inclusion of these rights, which seems clear, but to inquire about the origin of these ideas and how workers' rights made it into the constitutional text.

Mexico's legislative activity after the Revolution shows that the inclusion of worker's rights in the 1917 Constitution did not happen in a vacuum. Rather, it had an immediate precedent in the legislative work of states during the years of the revolution. Between 1914 and 1917 - from the overthrowing of General Victoriano Huerta to the victory of Carranza over the other revolutionary factions - a number of Mexican states enacted labour legislation recognizing a series of workers' rights. ${ }^{67}$ Some of these laws paid explicit attention to labour laws in other countries. ${ }^{68}$

The existence of foreign influence in the Constitution is evident from the comments in the Constitutional Assembly. In a revealing moment, Alfonso Cravioto made a now widely-cited pronouncement that compared the Mexican Revolution and its Constitution

\footnotetext{
${ }^{62}$ Ibid 43.

${ }^{63}$ Ibid.

${ }^{64}$ Ibid 52.

${ }^{65}$ De la Cueva, Nuevo Derecho 52. Nestor de Buen concludes a chapter about the history of social rights stating: "thus was born the first precept that granted rights to workers at a constitutional level. Mexico entered history as the first country that incorporated social guarantees in a Constitution." De Buen, Derecho del Trabajo 343; see also Diario de los Debates del Congreso Constituyente, 1916-1917, Mexico 1960.

66 Trueba-Urbina, Alberto, La Primera Constitución Político-Social del Mundo (Mexico, Editorial Porrúa,1971).

${ }^{67}$ De Buen Lozano, Derecho del Trabajo 329-334; De la Cueva, Nuevo Derecho 98-100.

${ }^{68}$ De Buen notes that these state laws that preceded the Constitution ranged from very simple to sophisticated legislations and that some included comparative law references. De Buen, Derecho del Trabajo 333.
} 
to the French revolution and its subsequent Declaration of the Rights of Man. ${ }^{69}$ Yet, in this same speech, Cravioto made an additional important revelation: he rose to defend Carranza and José Natividad Macías, who, in the heated debates, had been branded "conservatives" by the radicals. He praised Carranza's interest in labour, noting that "Carranza had commissioned Macías to go to the United States and study there, profusely, the future Mexican labour laws."

Similarly, labour scholar Alberto Trueba-Urbina, a staunch supporter of the originality of the Mexican Constitution, discusses the 1916-17 Constitutional Congress and the process of creation of Article 123. ${ }^{71}$ Among the many documents he refers to, however, one can find the very same project of the Commission for Article 123, headed by Natividad Macías, establishing the basis for labour legislation. In the Preamble, the influence of foreign ideas is evident:

$[\mathrm{T}]$ he useful lessons that foreign countries have given us, concerning the favourable conditions in which their economic prosperity takes place, due to the social reforms implemented ... suffice to justify this initiative, so that it can take effect this time and fill the existing gap of our codes, to maintain the desired equilibrium in the relationships between workers and employers, subordinated to the moral interests of humanity in general, and of our nationality in particular. ${ }^{72}$

It is clear that Mexican Congressmen were very aware of labour legislation in other parts of the world. There is an important difference between enshrining workers rights in the Mexican Constitution and claiming that workers' rights, or more broadly social rights, are the creation of the Mexican Constitution. There is no doubt that those participating in the Assembly deemed these rights necessary for the Mexican socio-economic conditions. But the legal, doctrinal, philosophical developments that led to the creation of those rights did not stem organically from the socio-economic conditions that the new constitution sought to remedy.

Some of Article 123's key provisions, including the eight-hour work day, the prohibition of child labour and the employer responsibility for workplace accidents, were the topics of Mexican and other countries' legislation before the Revolution. Consider the French doctrine imposing liability on employers for workplace accidents, moving away from fault or negligence liability and towards strict liability. ${ }^{73}$ The legal theory that the State could regulate relations between employers and workers directly by requiring a minima of conditions, rather than leaving those to the parties' free will; the moral idea

\footnotetext{
${ }^{69}$ Declaration of the Right of Man and the Citizen (France), 26 August 1789, www.unhcr.org/refworld/docid/3ae6b52410.html.

${ }^{70}$ Rouaix, Pastor, Genesis de los Articulos 27 y 123 de la Constitución Politica de 1917 (Colegio de la Frontera 1959) 89 (emphasis added).

${ }^{71}$ Trueba-Urbina, Derecho social 152.

${ }^{72}$ Ibid 153 (emphasis added).

73 De la Cueva, Nuevo Derecho 19 (the workers' compensation law - promoted by Minister WaldeckRouseeau and other members of the socialist party - was among the first French labour laws adopted after the War of 1870).
} 
that the state had an obligation to stop exploitation and improve the conditions under which workers laboured and lived; and the economic idea that this regulation was beneficial to society all existed before the debates in the Constitutional Assembly.

It is possible to believe that the inclusion of worker's rights in the Mexican constitution corresponded to a political opportunity that was seized by Mexicans influenced by these ideas at the end of the revolution. In this sense, the struggle for workers' rights and the idea of social law were connected to a truly international phenomenon. But to conclude that social rights - and more specifically workers' rights were the creation of the Revolution, the original creation of Mexican intellectuals and legal scholars or the product of the 1917 Constitution, does not stand in light of serious scrutiny.

\section{The Political Character of Labour Law}

\section{i. Labour Law as a Radical Political Project}

The twin argument of the national origin of social law in Mexico is that it was a politically radical program at its inception. The inclusion of workers' rights in Article 123 is portrayed as the result of a winner-take-all victory and the institutionalization of a radical program. The most notable labour law scholars in the country have certainly contributed to this idea, weaving a narrative of a legal regime with huge emancipatory potential.

According to several accounts, Article 123 was the triumph of the radical legislators over the conservatives in Congress. ${ }^{74}$ However, the most important triumph for the radicals was not the definition of the rights' content, which were already envisioned for a subsequent labour statute, but instead their inclusion in the Constitution itself. Although there seemed to be considerable agreement in the Assembly over the need to legislate workers' rights, their constitutionalisation was perceived as innovative and radical at the time.

There was a heated debate in the Constitutional Assembly about whether workers' rights should be included in the Constitution. Many thought it was enough to grant Congress the constitutional powers to legislate on labour regulation and argued for letting Congress pass a labour statute later. ${ }^{75}$ This position represented the view originally supported by Venustiano Carranza, the drafters of the Project of the Constitution and the faction of the renovators. This coalition was strongly opposed by a handful of radical Congressmen. In one of the most cited passages of the debates, Heriberto Jara argued:

[T]he jurists, the publicists, the general experts of legislation, will probably find ridiculous this proposition: How would a Constitution

\footnotetext{
${ }^{74}$ De Buen, Derecho del Trabajo 343.

${ }^{75}$ Fernando de Lizardi, UNAM Law School's Dean, initiated the debate by arguing against the inclusion of the new paragraph into the Constitution. He claimed it was unnecessary, as it was a set of "very good desires that will find an adequate place in Article 73 [stipulating Congress' powers] as a general basis for Congress to later legislate labour matters.” Rouaix, Genesis 77.
} 
include maximum work hours? How would it point out that the individual should not work more than 8 hours a day? That, according to them, is impossible; that, in their opinion, pertains to the regulation of [ordinary] laws. But precisely, what has this theory done? That our Constitution, so liberal, so broad, so good, had resulted in, as the Scientifics call it, 'a suit of lights for the Mexican people', because that regulation was never passed. ... The eight-hour work-day ... is to guarantee the freedom of individuals, it is precisely to guarantee their lives, to guarantee their energies, because until now Mexican workers have only been subject to exploitation. ${ }^{76}$

Several representatives delivered passionate speeches supporting this motion. ${ }^{77} \mathrm{~A}$ position to include workers' rights in the Constitution, even to create a whole new title, gathered momentum. ${ }^{78}$ When this trend seemed irreversible, Carranza commissioned representative José Natividad Macías to support the creation of a special constitutional section for labour. ${ }^{79}$ Macías had previously elaborated a labour code commissioned by Carranza, which was then the basis for what would become Article $123{ }^{80}$

The achievement of the radical faction in the Assembly consisted not so much in the content of workers' rights but in their inclusion in the Constitution. The radicals wished to enshrine what they saw as a key promise of the revolution, probably out of distrust that a future labour code would pass. This accomplishment should not be belittled. As can be gleaned from the constitutional debate, there was considerable opposition by the legal elite amongst the Congressmen. The radical faction succeeded in doing something that seemed unorthodox for the liberal jurists at that time; in defying the liberal constitutional models available, the radical Congressmen prioritized substance over form and succeeded in constitutionalizing workers' rights.

Labour scholars have made two common claims about the progressiveness of Mexican labour law that form part of the traditional narrative: first, that labour law had radical objectives and would inaugurate a new social and economic order; and, second, that these radical goals reached their apex during the government of President Lázaro Cárdenas (1934-1940), what is conceived of as the golden era for the legacy of the 1910

\footnotetext{
${ }^{76}$ Rouaix, Genesis 77-78. This passage is cited in every labour law book. See De la Cueva, Nuevo Derecho 49, Nestor de Buen, Derecho del Trabajo 343-352, Trueba-Urbina, Derecho Social 47-48.

${ }^{77}$ Hector Victoria, the representative of the state of Yucatán, a state that had already enacted a labour legislation" including "maximum daily hours, minimum wages, weekly rest, health in the factories and mines, industrial agreements, creation of tribunals of conciliation and arbitration, prohibition of evening work for women and children, accidents, insurances, compensation, etc.” Rouaix, Genesis 80.

${ }^{78}$ This position was advanced by Froylán Manjarrez, arguing that he did not "care whether this Constitution adjusts to the models foreseen by the jurists... what I care about is that we attend the clamour of the men that participated in the armed struggle and deserve that we look for their welfare ... Let us not fear that our Constitution be a little bad in its form ... let's go to the substance of the question." Rouaix, Genesis 81; Diario de los Debates del Congreso Constituyente, 1916-1917 (Mexico, 1960) 986.

${ }^{79}$ De la Cueva, Nuevo Derecho 50.

${ }^{80}$ Nestor de Buen, Derecho del Trabajo 345-46.
} 
Revolution. ${ }^{81}$ After Cárdenas, the story goes, these principles were subverted or betrayed by subsequent administrations and by the leadership of the labour movement.

De la Cueva was one of the most fervent advocates of the progressive character of labour law and its radical goals. He referred to the creation of social law as:

[T] he revolution of equality as a guarantee of liberty, dignity, and welfare for all human beings, a political and juridical system in which the Aristotelian phrase of justice "to give to every one his own" is substituted by the Marxist formula "to give to every one what he needs." 82

According to this view, labour law was a major victory for the working class. It was not only a protectionist law, but also created a status-based law of the working class. ${ }^{83}$ Article 123 stood for the elimination of the liberal distinction between private and public law, and for the creation of social law, which would give legal force to labour's struggle against exploitation and for social justice. ${ }^{84}$

Labour law scholars share nostalgia for labour law's presumed original radical aims and for their golden era under president Cárdenas's government. Cárdenas' support for the labour movement is praised and widely acknowledged. ${ }^{85}$ Scholars point to the end of Cárdenas' government as the turning point in the labour system. ${ }^{86}$ After the Cárdenas administration, the government began deradicalising and weakening labour unions, enabling the ratification of national unity agreements and demobilising the transformative character of the labour movement. ${ }^{87}$ For instance, the Confederation of Mexican Workers (CTM) - the largest labour organization ever in the country created with Cárdenas' support - substituted its radical slogan, "For a society without classes," with the more moderate one. "For the emancipation of Mexico." ${ }^{\prime 8}$ Labour scholars are both nostalgic

\footnotetext{
${ }^{81}$ De la Cueva, Nuevo Derecho; De Buen, Derecho del Trabajo; Trueba-Urbina, Derecho Social.

${ }^{82}$ De la Cueva, Nuevo Derecho LI.

83 Ibid.

${ }^{84}$ De la Cueva, Nuevo Derecho LVIII. Although scholars agreed on the progressiveness of labour law and saw it as a direct challenge to the liberal legal and economic order, they did not advance identical positions about labour law's objectives. Take, for instance, De la Cueva and Trueba-Urbina. While De la Cueva seemed to regard labour law as a powerful instrument to mediate between capital and labour within capitalism, Trueba-Urbina saw in labour law an institution that would set in motion a radical transformation away from capitalism and towards socialism. De la Cueva, Nuevo Derecho 85; Trueba-Urbina, Derecho Social 290-91; see also ibid 121-122, 235.

${ }^{85}$ De la Cueva, Nuevo Derecho LX, De Buen, Derecho de trabajo 372; Trueba-Urbina

${ }^{86}$ De Buen asserts, "[W]ith Cárdenas concludes the process of fundamental social reforms." After Cárdenas, Mexico "takes a definite route toward capitalism. It is not a classic liberal capitalism. ... It is a capitalism integrated on one hand with private resources and on the other, with an important state intervention .... with certain social direction.” De Buen, Derecho del Trabajo 376. This transition begins in 1940, only nine years after the enactment of the first federal Labour law in 1931.

${ }^{87}$ De Buen, Derecho del Trabajo 381.

${ }^{88}$ De Buen, Derecho del Trabajo 382. The CTM's original manifesto clearly expressed its socialist aims, declaring the abolition of the capitalist system as a mid-term goal. Ibid 375 .
} 
for Cárdenas' golden age and disillusioned by the de-radicalization of organized labour and of the labour regime in general. ${ }^{89}$

\section{ii. Labour Law as a Political Compromise}

Analyzing the constitutional debates in the 1916-1917 Assembly and the developments that led to Article 123, a different story is available: the labour regime did not emerge as a truly radical project that then declined and demobilized, as prominent labour scholars have argued, but, rather, it was a non-radical compromise from its inception. Pastor Rouaix, who chaired the Commission in charge of writing workers' rights' special title in the Constitution, provides a detailed account of this compromise. ${ }^{90}$ The preparatory work for the article generated heated debates before reaching a final decision. ${ }^{91}$ The outcome, according to Rouaix, was a compromise between the opposing factions participating in the Constitutional Assembly: "the meetings ... were the fraternal amalgam of Jacobins and moderates, renovators and military men, Carrancists and Obregonists, united by one sole flag: the flag of fatherland." 92

Rouaix's book sought to set the historical record straight after the publication of two books written by representatives in the Constitutional Congress. ${ }^{93}$ Both books' authors claimed credit for its respective faction for the social reforms implemented in the 1917 Constitution. ${ }^{94}$ That these authors could each appropriate the outcome of the Constitution - to some extent true - further confirms that Article 123 was a compromise between competing factions that suited both the "renovators" - whose leader was the main author of that Article - and the "radicals." 95

\footnotetext{
${ }^{89}$ See Trueba-Urbina, Derecho Social 124, De la Cueva, Nuevo Derecho 45 (complaining about the betrayal of labour law's goals and wondering if labour law would ever have the courage of its convictions); De Buen, Derecho del Trabajo 379.

${ }^{90}$ Rouaix, Genesis 105. Rouaix, a member of Carranza's cabinet, justifies his selection as chair of this commission by the trust he inspired in Congress: "[I]n the radicals because they knew his past performance as eminently liberal and revolutionary; in the military, because as Governor of the state of Durango ... he was one of the men who took up arms for the revolution; in the renovators and moderates for his civilian condition and for his adhesion to Mr Carranza." Ibid.

${ }^{91}$ Some representatives introduced concepts of "alarming radicalism," but the Committee sought agreement by consensus. Rouaix, Genesis 106.

92 Rouaix, Genesis 240. (emphasis added). Rouaix claims two alliances emerged at the outset in the Constitutional Congress: (1) moderates or "renovators" who recognized Venustiano Carranza as leader and Commander-in-Chief, represented in the Constitutional Congress by five former Congress representatives under Porfirio Diaz' dictatorship, and (2) radicals, grouped around General Álvaro Obregón, formed by military men who had fought the revolution, surrounded by young representatives. Ibid 229.

${ }^{93}$ See ibid 229-240.

${ }^{94}$ Ibid 229-240. These books are Chronicle of the Constitutional Congress by Juan de Dios Bojórquez, a leftist and friend and supporter of Obregón, and History of the 1917 Constitution by Felix F. Palavacini, "reformer" who supported Carranza. Ibid 231.

${ }^{95}$ Rouaix, Genesis 237, 239. Rouaix claims that both books distort the participation of the opposite faction to take credit for the final work. In contrast, his book reflects the impartiality of someone who served as a "loop of union between exalted extremes, which made possible a great creation." Ibid 237.
} 
Additionally, Social Catholicism was an apparent influence in this ultimate compromise. The meetings took place at the chapel in the Bishop of Querétaro's residence, where "the theoretical principles of Christianity, which so many times had been praised in that place, had their practical realization" "Th That the Commission's chair saw Article 123 as an application of the principles of Christianity, even in its most progressive articulation at that time, further suggests that the compromise was far from being a radical victory.

Furthermore, even the labour movement's golden era, under Cárdenas, looks less radical that what many scholars portray. ${ }^{97}$ Cárdenas can be read as explicitly forging a compromise position:

The main action of the Revolution's new phase is Mexico's march toward socialism, movement that equally sidetracks from the anachronistic norms of classic liberalism and from those of communism.

Within this doctrine, the Mexican state is not limited to be a simple guardian of order, with tribunals to adjudicate according to the law of individuals; neither can it become the head of the national economy, rather it tends to turn into the regulator of the great economic phenomena registered in our regime of production and wealth distribution. ${ }^{98}$

What Cárdenas calls socialism is, in his words, right in the middle of the two radical political options: liberal laissez-faire and communism. Cárdenas describes Mexico's revolutionary path as a compromise between these two positions, in which a private property capitalist system is maintained and moderated through government intervention.

Interestingly, the same scholars who assert Article 123 is a victory of a radical political position acknowledge Cardenas' less than radical actions and legacy regarding labour unions. De Buen, for instance, claims that Cardenas' legacy to the labour movement was the creation of a national labour confederation, the CTM, with a socialist orientation. He explains that Cárdenas created the CTM to weaken and replace the then largest labour confederation, the Mexican Regional Confederation of Workers (CROM), which was strongly associated with Cárdenas predecessor, former President Calles. Thus, Cárdenas needed a labour organization that would support his administration and his policies. ${ }^{99}$ De Buen notes that even though CTM had originally a Marxist orientation, it was never, not even at its creation, a combative union. Rather, the CTM "was born

\footnotetext{
${ }^{96}$ Ibid 104.

${ }^{97}$ For an analysis of different historical interpretations of Cárdenas' legacy see Knight, Alan, "Cardenismo: Juggernaut or Jalopy?" (1994) 26 Journal of Latin American Studies 73-107 (arguing that Cardenismo had radical objectives but was institutionally weak and was hijacked by more moderate groups and by opponents). "After 1940, the key institutions of Cardenismo ... hardly fulfilled the radical high hopes of the mid- I930s; nor, to put it another way, did they realise the lively fears of businessmen and conservatives." Idem.

${ }^{98}$ Navarrete, Alfredo, Alto a la Contrarrevolución (Testimonios de Atlacomulco) (Mexico, Editorial Libros de Mexico 1971) 11.

${ }^{99}$ De Buen, Derecho del Trabajo 372.
} 
demobilized," since it was Cardenas' instrument to fight CROM's political force. ${ }^{100} \mathrm{De}$ Buen concludes that Cardenas' formidable work is not exempt from errors: "[ $\mathrm{H}[$ is love for labour unity led him to create an organism that was later to represent the most negative aspect of the labour movement."101

Employers accused Cárdenas of being communist. ${ }^{102}$ As a response, in his labour policy agenda, Cárdenas explicitly rejected the influence of any communist groups in his administration, argued for the need to create a single worker's organization to end industrial conflict, reinforced the role of the government as arbitrator of social life, and stressed that workers' demands would always be considered within the margins of firms' economic possibilities. ${ }^{103}$

A final word about the labour movement before Cárdenas's administration is in order. Scholars refer to the syndicalist group "La Casa del Obrero Mundial" as combative and with revolutionary aspirations until its leaders made an agreement with Venustiano Carranza in 1914 to join the Revolution. ${ }^{104}$ De Buen notes that "in that moment, the demobilized unionism was born." ${ }^{\text {"105 }}$ During the period from Carranza to Cárdenas (19171934) the cooptation of unions, or their corporatist alliance with the government, and their transformation into political instruments was accomplished. ${ }^{106}$

These accounts provide a picture of a labour movement at odds with the radical character that labour law scholars often project onto the past. While there were clearly radical elements in the labour movement, it seems that right after the Revolution, most unions came into the fold and compromised with the state. They forewent their radical aspirations in exchange for government protection and benefits. Cárdenas' golden era seemed to have continued this corporatist logic. Even if he was pro-labour, as Cárdenas undoubtedly was, he successfully created the CTM to consolidate his political power. The CTM stands today, as the monument to corporatism and official unionism, far removed from any progressive agenda.

\section{iii. A Typology of the Political Character of Social Law}

The compromising character of the "social" was not limited to the case of Mexico. ${ }^{107}$ Moreover, critiques of classical liberalism seeking to reconstruct the legal system around the idea of the social were not necessarily associated with the left or the right. The term

\footnotetext{
${ }^{100}$ Ibid 375.

101 Ibid 376

102 Ibid.

103 Ibid 373-75.

104 Ibid.

105 Ibid 365.

${ }^{106}$ De Buen classifies unions into moderate and submissive "yellow-dog" unions and the anarchist "red" anarchist, which regarded the state as the handmaiden of the bourgeoisie set out to ensure capitalist exploitation. President Calles would effectively incorporate the "red" unions into the National Revolutionary Party - later the PRI - in 1929. Ibid.

${ }^{107}$ See Kennedy, Duncan and Belleau, Marie-Claire, François Gény aux États-Unis, in Thomasset, Claude, et al, eds, François Gény, Mythe Et Realités, (Yvon Blais 2000).
} 
"social" could be claimed by anyone not associated with Marxism or liberalism. ${ }^{108}$ Indeed, the strength of the social was that it did not associate ideologically with the political divisions of the time. ${ }^{109}$ As to the role of the State, the social favoured equally a reconstruction through the State and a reconstruction through civil society. Thus, the social encompasses two divergent positions with regard to the question of labour: one position for social regulation by the State, and another in opposition to State regulation. $^{110}$

The nature of the social compromise in Mexico was a progressive move from the old classical, liberal legal and economic regime, not a conservative one. It was a corporatist project, but it was not fascist. It was decidedly not a radical project; it was far from being a communist program or to even contain the seeds of it. The groups that did not participate in the reconstruction of the legal order through the State were those who represented the old, liberal capitalist system associated with Diaz's regime and those who wanted a communist regime. The reconstruction was also a secular compromise, not a religious one. The groups that desired a reconstruction through civil society and opposed the State remained at the fringe. This includes groups from both the left and the right. On the left, anarchist groups regarded the State as perpetually in alliance with the dominant capitalist class that oppressed workers and peasants. On the right, Catholic groups resented the State for limiting the role of the Church in public and private affairs, and for limiting religious expression while propagating a secular ideology. These groups entered into conflict with the State at different points following the 1917 Constitution, as the new compromise was consolidating.

\section{Explaining the Traditional Narrative}

If these critiques are plausible, two questions emerge: First, why did these scholars argue so adamantly for the national and radical character of labour law? Second, why does it matter? I see at least three main projects furthered by this narrative.

(1) The professional project. These scholars created a new field in legal scholarship labour law - and at the same time claimed to be renovating the whole legal system around the idea of social law. This project opened up space for progressive scholars and situated them at the vanguard of an otherwise formalistic and doctrinal private law scholarship. ${ }^{111}$ These scholars became the standard-bearers of a fully-fledged renovation of the legal system.

\footnotetext{
108 Ibid 300 .

${ }^{109}$ Ibid; see also Kennedy, Duncan "From the Will Theory to the Principle of Private Autonomy: Lon Fuller's 'Consideration and Form"” (2000) 100 Columbia Law Review 94 119-120 (arguing that before World War I social reconstruction did not require the adoption of communist or fascist versions of collectivism because neither yet existed as a developed theory or practice of state power).

${ }^{110}$ Kennedy and Belleau, François Gény 301; see also Kennedy, Will Theory, 119-120.

${ }^{111}$ Nevertheless, private law was also being socialized. See Galindo Garfias, Ignacio, Estudios de Derecho Civil (Universidad Nacional Autónoma de Mexico 1981); De Buen, Néstor, La Decadencia del Contrato (Editorial Porrúa 2000).
} 
This professional project emerged from a theoretical and doctrinal breakthrough adopted, crafted and claimed as theirs in the domestic legal academy. To gauge the impact on these scholars' professional careers consider the case of De la Cueva, who became not only a renowned legal scholar but also a public intellectual and a government advisor. Labour law became a springboard into constitutional law, legal theory and legal philosophy. ${ }^{112}$ Founding the field of labour law marked the beginning of a stellar professional career. He became President of the Universidad Nacional Autónoma de Mexico (UNAM) in 1936-1942, Dean of the UNAM Law School in 1952-54, and later Emeritus Professor of Law, and Doctor Honoris Causa. De la Cueva received, from the President of Mexico, the 1978 National Prize of Arts and Sciences in History, Social Sciences, and Philosophy. He is also revered as a professor and remembered as a mentor by many law students who would later become legal scholars, writers, and politicians. Thus, De la Cueva's creation of the labour law field, along with other renowned scholars, can be seen as an effort to forge a professional project, which involved a serious intellectual agenda and a claim to expertise, a career ambition in the legal academy and state institutions, and a desire to influence his peers as well as future generations.

(2) The political project. Labour scholars intervened in the national questions about distribution of wealth and power. Questions such as how to organize relations of production between business and workers, how to allocate power between capital and labour, and what the state's role should be in mediating among them and through which institutions should the state intervene. De la Cueva, for instance, drafted the project for the sentence of the Supreme Court's Labour Law Chamber that was the basis for the oil companies' expropriation decree by President Lázaro Cárdenas. He was also Chair of the Commission that wrote the second federal labour statute, enacted in 1970, which was an effort to reinvigorate worker protections and renovate some of the redistributive and transformative aspirations that De la Cueva believed had stagnated.

Notably, the political project can be seen as facilitated by the professional one, with its claim to authoritative knowledge and expertise. The professional project is also a struggle for the prevalence and influence of ideas that are deemed to have better economic and social consequences in society. For De la Cueva, labour law was not only a new discipline but also, and perhaps primarily, a new tool for the social and economic transformation of the country.

(3) The transnational project. This is a project that seeks to establish a new relationship of equals between the geopolitical periphery, where Mexico is situated, and the centre. In this case, De la Cueva and other labour scholars attempted to establish this relationship by arguing that Mexico had transcended, or anticipated, Europe. ${ }^{113}$ They

\footnotetext{
${ }^{112}$ De la Cueva was the first scholar in Mexico to publish a book on labour law (1934). Later, he translated Herman Heller's book on Sovereignty: A Contribution To a Legal Theory of the State and International Law (1965), published The Idea of the State in 1975, Constitutional Theory in 1982, and The New Mexican Labour Law (1985), among a long list of other writings.

${ }^{113}$ For an incisive analysis of the appeal to identity in the project of nation-building, to provide social cohesion and justify a domestic political project see Geertz, Clifford, The Integrative Revolution: Primordial Sentiments and Politics in the New States, in Old Societies and New States: The Quest for Modernity in Asia and Africa (New York, Free Press of Glencoe 1963) 105-157 ("[P]eoples of the new
} 
claimed the genesis of social rights and pointed to the 1917 Constitution as the first "social" constitution in the world. De la Cueva asserts, "We can affirm that life anticipated doctrine, because in 1917 ... the first Declaration of Social Rights in history was proclaimed in Querétaro [México], and two years later in Weimar."114

This claim lent enormous credibility to the national project of reconstruction. Furthermore, claiming that the project was progressive enabled these legal scholars to advocate for progressive politics in the Mexico by reference to the Constitution. It was a claim of progressive originalism. When new questions of interpretation arose, they could argue that the Constitution required the progressive one.

This would not be the first time that legal scholars participated in creating a narrative of national pride. For example, in many of the newly independent states in Latin America in the nineteenth century, legal elites claimed a specific uniqueness or identity for their country that preceded the Spanish colonialists and differentiated the new nation from Spain. This uniqueness allowed them to claim a place in the concert of nations as an independent and sovereign entity and provided cohesion for the domestic project. ${ }^{115}$ Legal scholars in several Latin American countries were actively involved in defending the sovereignty of their countries. They were busy creating new legal doctrines that would allow their countries to be shielded from threats of foreign intervention. These doctrinal innovations were touted as coming out of the new countries, belonging to the tradition of, while simultaneously renewing, international law. ${ }^{116}$ Thus, these scholars would claim that Latin American international law had contributed something original to the discipline, demanding recognition as peers in the international arena. This claim allowed them to legitimate the projects of their national governments at home.

Although these three projects are analytically distinct, they are no doubt intermingled. For instance, in De la Cueva's case, these projects reinforce each other in important ways. The transnational project advocating a historic national contribution seems instrumental to enable his professional and political projects domestically. International

states are simultaneously animated by two powerful ... motives ... - the desire to be recognized as responsible agents whose wishes, acts, hopes, and opinions 'matter,' and the desire to build an efficient, dynamic modern state. The one aim is to be noticed: it is a search for an identity, and a demand that the identity be publicly acknowledged as having import, a social assertion of the self as 'being somebody in the world.' The other aim is practical: it is a demand for progress, for a rising standard of living, more effective political order, greater social justice, and beyond that of 'playing a part in the larger arena of world politics,' of 'exercising influence among the nations.'”); see also Hosbawm, Eric and Terence Ranger, Terence, eds, The Invention of Tradition (Cambridge University Press 1983); Weber, Max, The Nation, in Weber, Max, Mills, C. Wright and Gerth, H. H., eds., From Max Weber: Essays in Sociology (Routledge 1969).

${ }^{114}$ De La Cueva, Nuevo Derecho 71.

${ }^{115}$ See Becker Lorca, Arnulf, "International Law in Latin America or Latin American International Law? Rise, Fall, and Retrieval of a Tradition of Legal Thinking and Political Imagination" (2006) 47 Harv. Int'1 L.J. 283, 301-302; Obregón, Liliana, "The Colluding Worlds of the Lawyer, the Scholar and the Policymaker: A View of International Law from Latin America" (2005) 23 Wis. Int'l L.J. 145, 157-58.

${ }^{116}$ See generally Alvarez, Alejandro, "The New International Law" Transactions of the Grotius Society, Vol 15 (Papers Read before the Society 1929) 35-51. 
recognition gives credence to De la Cueva's professional aspirations and opens the space for political intervention at home.

So why is it important to problematize the traditional narrative and to show its biases, make-beliefs and contradictions? In my view, there are at least two compelling reasons. First, it has the potential to render the three projects - professional, political and transnational - visible and, thus, open them up for contestation. Challenging the traditional labour law narrative may open the field to new ways of thinking about labour relations. The challenge may also foster legal institutional imagination and policy innovation.

Second, questioning the traditional narrative may enable a clearer analysis of the consequences of the status quo. At one level, the analysis may illuminate who wins and who loses under the current narrative - whose professional and political projects are advanced and whose are hindered. At another level, the challenge may facilitate a more concrete analysis of the consequences of the labour law regime in place by examining how specific rules and institutions affect the distribution of wealth and power in society.

In the past, social law advocates failed to engage with a number of important critiques to social legislation, coming from all sides of the political spectrum. Feminists challenged labour regulation for its gender bias, creating a division of labour that relegated women to the household and left them out of the market. When women did enter the market, they were discriminated against with fewer opportunities and lower wages. ${ }^{117}$ A liberal critique challenged the corporatist character of social law, noting that the labour law regime relied on an alliance between the government, employers and official unions that impinged on worker liberty, and led union leaders to disregard the interests of the rank and file, focusing instead in obtaining personal and political benefits in exchange for agreements. ${ }^{118}$ Social theorists and social movements challenged the social law regime of the welfare state as a statist, bureaucratic system of social control in the service of liberal capitalism. The labour law regime, worked to create an obedient working class that was trained to respect authority and accept its limited and subordinated role in decisions of economic production and distribution. ${ }^{19}$ Finally, neoclassical economists challenged

\footnotetext{
${ }^{117}$ See eg Ariza, Marina, Mercados de Trabajo Urbanos y Desigualdad de Género en México a Principios del Siglo XXI, in De la Garza, Enrique and Salas, Carlos, eds, La Situación del Trabajo en Mexico 393 (Mexico City, Instituto de Estudio del Trabajo 2003) (noting large disparity in economic earning power between men and women); Williams, Joan, Unbending Gender: Why Family And Work Conflict And What To Do About It (Oxford University Press 2000) (discussing ways to alleviate the conflict between domestic and workplace responsibilities by altering labour market opportunities); Fineman, Martha, The Neutered Mother, The Sexual Family And Other Twentieth Century Tragedies (Rutledge 1995) (arguing for direct public support of care work but not through marriage).

${ }^{118}$ See eg Alcalde, Arturo and Luján, Bertha, Como Viven La Democracia Los De Abajo 91 (Universidad Nacional Autónoma de México 1997).

${ }^{119}$ See Bensusán Graciela, El Modelo Mexicano De Regulación Laboral 27-45 (2000) (analyzing different interpretations of the role of labour law and of the state in liberal capitalism); Klare, Karl E, Labor Law as Ideology: Toward a New Historiography of Collective Bargaining Law (1981) 4 Industrial Relations Law Journal 450-482..
} 
labour regulation as a barrier to job creation, firms' competitiveness and economic growth. ${ }^{120}$

Some of these critiques are more warranted than others, and their veracity depends on each particular context. ${ }^{121}$ They are critiques of social law and of labour regulation by advocates on the left and on the right of the political spectrum. What they have in common is that they are consequentialist. They focus on labour regulation's effects on different groups of workers: female workers, youth, non-unionized or informal workers; on workers' subjectivity and their role in society; on workers' ability to be represented; on employers; and on the economy as a whole.

Defending social law - or labour rights - as a national asset and as the achievement of a revolutionary struggle or as a fundamental pillar in the Constitution are ways to justify a social law regime without addressing its effects. In this way, advocates for labour miss an opportunity to evaluate the consequences of the labour regulation they defend and to engage with critics on their own terms. Once the national identity argument is put aside, new opportunities to both defend some aspects of the current regime and to re-imagine it become apparent.

The critiques of the use of national identity and of the assumption that social law in Mexico is progressive may serve as a warning against the romanticisation of social law as a transformative project. Mexico shows that identity-based and deontological arguments can be successful in creating national pride and mobilizing support for specific institutions; but they cannot justify a legal regime based on its effects. Moreover, these arguments might end up legitimating a regime that does not advance workers' welfare.

Currently in Mexico, many progressives resist the neoliberal flexibility program by invoking the achievements of the revolution and the 1917 Mexican Constitution. They assert that the current legal and constitutional framework has a progressive character that can help resist calls to dismantle current labour market regulation. As I have examined, however, treating social law as having an inherently progressive character is not historically warranted in the case of Mexico. When progressives retrench behind national pride or constitutional rights' arguments to resist the neoliberal flexibility reform they implicitly concede too much. When their main line of defence is that workers' rights cannot be touched, they concede that the economic effects of current labour law regime might as well be negative but that they do not have an answer to that challenge. Moreover, this line of defence also makes it harder to think of imaginative, progressive alternatives to current market regulation.

On the other hand, those advocating for neoliberal flexibility reform increasingly use the malleable social law discourse to make their case. In Mexico, this is most evident in the PRI bill, which argues that flexibility reforms are necessary to help workers. ${ }^{122}$ The bill claims that the historical achievements of the Revolution and workers' rights

\footnotetext{
${ }^{120}$ See e.g. Velasco, Gustavo, Labor Legislation From An Economic Point Of View (Liberty Fund 1973); Friedman Milton \& Friedman, Rose D, Free to Choose, 228-47 (1979).

${ }^{121}$ Santos, Alvaro, "Labor Flexibility, Legal Reform, and Economic Development" (2009) 50 Va. J. Int'l L. 43-106.

${ }^{122}$ PRI bill at 20.
} 
consecrated in the Constitution will remain untouched. ${ }^{123}$ It is perhaps fitting for the PRI to advance such reform. After all, it is the party that institutionalized the national revolution and used that discourse to legitimate its rule. Now, having been out of power for twelve years, the PRI is trying to craft a compromise between employers' associations and unions. Despite its rhetoric, however, this compromise is likely not to benefit most workers.

A striking feature of the PRI bill is that it frames a neoliberal flexibility program for market regulation as a social law program. Thus, the PRI bill maintains that greater flexibility in hiring and firing is necessary to help create jobs, particularly for women and youth, and to promote competitiveness, productivity and growth. ${ }^{124}$ PRI promotes these reforms while claiming that it is motivated by the historical achievements of enshrining workers rights in the Constitution, which will continue to guide labour market regulation. At best, this bill is a promise to legalize the status quo.

\section{E. Implications of the Mexican Story for Debates in Other Countries}

The Mexican story offers several valuable lessons for labour law debates in other countries. First, Mexico shows that, despite is traditional association with progressive politics, the social is politically indeterminate. As an international phenomenon, social law took different political valences in different countries, from left to right in the political spectrum and from democratic to authoritarian forms of government.

Second, Mexico shows that arguments based on national identity and constitutional rights face serious problems. These arguments often fail to diagnose the effects of current labour market regulation, offer no response to consequentialist critiques of current regulation and offer no proposals for reimagining labor regulation to increase workers' wellbeing. Consequently, if neoliberals promote a flexibility reform couched on social law ideals, pro-labour advocates have a hard time offering an alternative program.

Third, the social was in fact a truly global phenomenon, despite claims that it was unique to and created by each country where it was introduced. This is important to keep in mind, because the arguments of national identity and constitutional rights considerably constrain the analysis to a specific country. Taking seriously the social's transnational character would help to analyze that country's situation in the global economy, thinking of how it is affected by its place in the world market and its relationship with other countries.

In the next section, I explore the relevance of the insights from Mexico for contemporary debates about labour regulation elsewhere, specifically in Europe. The effects of market economic integration in the EU and the perceived hampering of social provisions in the Member States have sparked a debate about the need to ensure the preservation of basic social protections as part of the Union. This debate has been framed in terms of identity and the allegedly inherent progressiveness of social law. I will

\footnotetext{
123 Ibid 22.

${ }^{124}$ Ibid.
} 
examine parallels between Europe case and Mexico and use the insights gained from the case of Mexico to raise some caveats.

\section{National Identity in Current Debates about Social Regulation in Europe}

In Europe, the social position has also been articulated on identity terms at the regional level. Advocates and scholars associate the creation of "Social Europe" with values that are considered indigenous to the Union and, therefore, must be defended on those terms. This is not limited to social regulation; these arguments are also advanced in private law, as it is visible in the debate about harmonization and the call for a "common core" that reflects European social values. ${ }^{125}$

Simultaneously, at the national level, advocates of social regulation resort to a similar identity argument to defend their welfare state' worker protections and social insurance programs against what is perceived as menacing European economic integration model. In this view, the EU's market-oriented policies threaten the existence of the welfare state and, with it, something fundamental about the nation's identity. This national level pushback against the EU model may be particularly acute now in the aftermath of the financial crisis.

This is not to say that all social position arguments are premised upon national or regional identity; however, these arguments remain powerful and thus, deserve critical scrutiny. For progressives, the obvious upside of defending social law on the basis of identity is that it provides an easy and energizing point of resistance. The problem is that identity conjures up essences and obfuscates trade-offs and distributional consequences. It also portrays the status quo as desirable and makes it harder to articulate alternatives to the existing law that could potentially better meet progressives' underlying interests and goals. Lastly, the emphasis on national identity eschews analysis of social regulation's implication in transnational problems with transnational constituencies. ${ }^{126}$

\section{A. The Use of Identity and the Push to Constitutionalize Social Rights}

Since the start of the European integration project after World War II, whether and how to regulate social policy at the supranational level has remained a central question. Progressives in Europe have widely used identity arguments to promote a social rights agenda, which is evident in the debates over "Social Europe." Take, for instance, the debate over the contents of a potential European Constitution, which was in the works in the early 2000s. ${ }^{127}$ Similar to Mexico, identity was a key force mobilizing the

\footnotetext{
${ }^{125}$ See The Study Group on Social Justice in European Private Law, "Social Justice in European Contract Law: a Manifesto" (2004) 10 European Law Journal 653, 655 (private law an "expression of cultural identity" and not merely technocratic; therefore should reflect European social justice agenda); see Kennedy, Duncan, Thoughts on Coherence, Social Values and National Tradition in Private Law, in Hesselink, Martijn, ed, The Politics of a European Civil Code (Kluwer Law International 2006).

${ }^{126}$ See e.g. Trubek, David M., Mosher, Jim and Rothstein, Jeffrey S., Transnationalism in the Regulation of Labor Relations: International Regimes and Transnational Advocacy Networks (2000), 25 Law \& Social Inquiry 1187-1211.

127 The Constitution was ultimately rejected. See Qvortrup, Matt, "The Three Referendums on the European Constitution Treaty in 2005” (2006) 77 The Political Quarterly, Volume 89, 89-97.
} 
establishment of social rights. European progressives argued that European identity was closely connected to the "social" because of the history of welfare protection in Member States, and, thus, constitutionalizing this social identity was the way forward for the EU.

Jurgen Habermas famously asked for the constitutionalization of Europe's social self. He argued that it was these values, in part, that set Europe apart from the rest of the world and which could provide the necessary glue for the further integration that was sorely needed in the face of unfettered globalization:

In Western Europe ... the political tradition of the workers' movement, the salience of Christian social doctrines and even a certain normative core of social liberalism still provide a formative background for social solidarity. In their public self-representations, Social and Christian Democratic parties in particular support inclusive systems of social security and a substantive conception of citizenship, which stresses what John Rawls calls 'the fair value' of equally distributed rights. In terms of a comparative cultural analysis, we might speak of the unique European combination of public collectivisms and private individualism. ${ }^{128}$

Miguel Maduro, who later served as Advocate General in the European Court of Justice (ECJ), called on the EU to initiate an open discussion on its "social identity" and its "social self" in the constitutional debates. Maduro noted the "subsidiary and underdeveloped nature of Europe's social citizenship when compared with its original market citizenship" and argued that whatever social rights the EU had granted its citizens, it had done so by virtue of the economic value of these citizens rather than respect for their basic dignity. ${ }^{129}$ His account of why Europe needed to constitutionalize the "social" explicitly relied on identity:

Simply stated, Europe must, as Kierkegaard would say, discuss its identity. ... As it now stands, and in Kierkegaard's terms, it faces despair: the despair of wanting to be oneself and the despair of not wanting to be oneself. I do not know the resolution but I believe that future developments of the Union depend on a discussion of this identity or, perhaps better, on a discussion of its underlying social contract. ... To ignore this "social identity question" in the forthcoming constitutional debates of the European Union may well correspond to the dangerous path of which Kierkegaard warned: "The biggest danger, that of losing oneself, can pass off in the world as quietly as if it were nothing; every other loss, an arm, a leg, five dollars, a wife, etc., is bound to be noticed."130

\footnotetext{
${ }^{128}$ Habermas, Jürgen, "Why Europe Needs a Constitution” (2001) 11 New Left Review 5, 10. “As Göran Therborn remarks: "the European road to and through modernity has also left a certain legacy of social norms, reflecting European experiences of class and gender . . . Collective bargaining, trade unions, public social services, the rights of women and children are all held more legitimate in Europe than in the rest of the contemporary world. They are expressed in social documents of the EU and of the Council of Europe."

${ }^{129}$ Maduro, Miguel Poiares, "Europe's Social Self: “The Sickness Unto Death" (2000) 2 conWEB Webpapers on Constitutionalism \& Governance beyond the State, www.bath.ac.uk/esml/conWEB 22.

${ }^{130}$ Maduro, "Europe's Social Self" 22.
} 
These positions share a reaction to the negative consequences of market integration in Europe and an identity-based project of building "Social Europe" as way to include social values in a future European Constitution. ${ }^{131}$ The aim was that, once constitutionalized, social rights could provide the social insurance and solidarity mechanisms to reshape economic integration. Social rights would thus achieve equal status with the economic freedoms and the efficiency rationale thus far driving the integration process. ${ }^{132}$

\section{B. Identity as Resistance}

Just as social progressives in Mexico use the supposedly close connection between national identity and the "social" to resist neoliberal reforms, social progressives in individual European states also resisted the process of further Europeanization through appeal to national identity.

Take, for instance, the French "no" campaign against the Constitutional Treaty. The campaign referenced the danger that the imagined low-wage immigrant, such as the "Polish plumber," constituted for the French social model and the danger that expansion to the East would constitute for French identity. ${ }^{133}$ A group of entrepreneurs intervening in favour of the "yes" vote felt compelled to answer the appeal to national identity. They argued that a France weakened by a "no" vote would have less influence in the deliberation over the European social model and would not be as able to push for the fundamental values of French society at the European level. ${ }^{134}$ Economist Frédéric Lordon reproached the "yes" camp for failing to note that "the social State and public services [are] ... fundamental elements of political and symbolic French grammar" and, thus, "[France] can't renounce them under any circumstances.",

National identity defences of the social welfare model has been even stronger in certain Scandinavian countries, where national identity has been constructed in close connection with the welfare state. ${ }^{136}$ Writing on the Nordic model, Mary Hilson notes

\footnotetext{
${ }^{131}$ Habermas was not unaware of the problem of potential conflicts that might arise in interpreting these values, but he saw constitutionalization as a mode of initiating a far non-existent pan-European civic public sphere that would allow Europeans to debate the issues. Armstrong, Kenneth, Governing Social Inclusion: Europeanization through Policy Coordination (Oxford University Press 2010) 234.

${ }^{132}$ For a famously sceptical take on the desirability of constitutionalizing Europe's "social identity," see Weiler, J.H.H., "A Constitution for Europe? Some Hard Choices" (2002) 40 Journal of Common Market Studies 563, 570. Weiler argued that Europe should not promise a social redistribution it will not be able to deliver, and, more importantly, it should not foreclose discussion on what the socially progressive choices mean by constitutionalizing current contested understandings of social rights.

${ }^{133}$ Arnold, Martin, "Polish Plumber Symbolic of All French Fear About Constitution" Financial Times (28 May 2005) www.ft.com/intl/cms/s/0/9d5d703a-cf14-11d9-8cb5-00000e2511c8.html\#axzz21o3Kr8le

${ }^{134}$ Institut de l'Entreprise, Appel des Entreprises en Faveur du OUI au Référendum Constitutionnel (2005) www.institut-entreprise.fr/fileadmin/Docs_PDF/Manifestations/dossier_de_presse_180505.pdf, 3 .

${ }^{135}$ Lordon, Frédéric, "Le Mensonge Social De La Constitution: Le Oui Entre Vaines Promesses et Imprecations" 9, www.fredericlordon.fr/textes/crise/tce/pdf/Mensonge_social.pdf

${ }^{136}$ Hilson, Mary, The Nordic Model: Scandinavia since 1945 (London, Reaktion Books 2008) 87-88; Schmidt, Vivien A., European Elites on the European Union: What Vision for the Future? in Gamble, Andrew and Lane, David eds, European Union and World Politics: Consensus and Division (London, Palgrave Macmillan 2009) 6 ("“T]he failures of Denmark and Sweden to join the euro ... [were] based on fears about the EU's impact on the highly generous welfare state, along with sovereignty and identity
} 
that "the welfare state is still regarded as an integral part of the meaning of Scandinavia." 137 The difference Scandinavian countries perceive between themselves as an "egalitarian social democratic community of destiny" and the "capitalist and Catholic European continent" fuels opposition to European integration. ${ }^{138}$ This identity-based defence of the welfare model has also resulted in a xenophobic discourse that specifically singles out foreigners as a potential burden to the generous welfare regimes of the north. ${ }^{139}$

While the project of national resistance may share the objective of social protection with those seeking to Europeanize social rights through treaty incorporation, it does not share their optimism that regionalization of social policy would be effective or ultimately beneficial. It is not surprising that some of the most vociferous opposition has taken place in countries with robust welfare systems, which fear that these hard-fought protections would be eroded. Remarkably, both groups use identity as a strategy to mobilize their agenda. At the regional level, social advocates mobilize European identity to propose a positive program of reform in the EU treaty and institutions; other social advocates mobilize national identity to resist the further encroachment of EU law on their national social protections.

\section{Identity to What Effect?}

Social progressives' call for the Europeanization of social rights was partly answered by the Constitutional Treaty, which ultimately failed, and the Lisbon Treaty, which largely replicated the Constitutional Treaty's provisions, and was accepted and entered into force. The Lisbon Treaty also incorporated by reference the Charter of Fundamental Rights, which includes a series of social rights, even though it explicitly excludes an interpretation that would widen the scope of the EU's competences. ${ }^{140}$ Moreover, on social policy, the EU is said to be a "social market economy" 141 striving for "smart, sustainable, and inclusive growth," 142 while the European welfare states are featured in the Commission's reports as a "productive factor" rather than as an impediment to growth. ${ }^{143}$

What have been the effects of the inclusion of social policy in the EU? I suggest that the relevance of social policy language in EU law has been tested in two crucial ways.

concerns."); see also Lubbers, Michael "Regarding the Dutch 'Nee' to the European Constitution. A Test of the Identity, Utilitarian and Political Approach to Vote No" (2008) 9 EU Politics 59-86

${ }^{137}$ Hilson, The Nordic Model 88.

${ }^{138}$ Ibid. 25-26.

139 "'[S]ome would see the Nordic welfare states as vulnerable to the related external pressures of European integration and immigration. The debates on Nordic EU membership during the mid-1990s reflected these fears.." Ibid. 112.

${ }^{140}$ Barnard, Catherine, EU 'Social' Policy: From Employment Law to Labour Market Reform, in Craig, Paul and De Burca, Grianne, eds, The Evolution of EU Law (Oxford University Press 2011) 658-660. For thorough assessment of the changes in social policy brought by the Treaty of Lisbon see Armstrong, Social Inclusion 241-255.

${ }^{141}$ Treaty on European Union, Art. 3(3) OJ-C 191 of 29 (July 1992)

${ }^{142}$ Commission Communication, "Europe 2020, A strategy for smart, sustainable and inclusive growth" COM (2010) 2020.

${ }^{143}$ Commission Communication, 'Social Policy Agenda,' COM (2000) 379, 3. 
The first test has taken the form of a string of highly controversial cases in the ECJ, where national collective bargaining regulations were in tension with EU economic freedom rights. The second test has been provided by the ongoing Euro financial crisis and the European response to tackle it. At a moment of crisis, how the rescue program takes shape would reveal how substantive the commitments to social protection are and whether the social agenda's aspiration to reshape Europe's economic integration has any chance to succeed. So far, the evidence, although not the rhetoric, seems to suggest otherwise. $^{144}$

First, a new phase in the resistance to Europeanization began after a series of decisions by the ECJ between 2007 and 2008 created intense anxiety about the future of the Nordic model, especially regarding collective bargaining. ${ }^{145}$ The Viking case, in which a Finnish ship sought to reflag under an Estonian flag in order to lower its labour costs, provoked strong reactions. ${ }^{146}$ The ECJ ruled that industrial action aimed at stopping an undertaking from exercising its freedom of establishment was a prima facie violation of the Treaties. Worker protection was a legitimate goal in the industrial action of the union, but it would have to be established by the national courts that specific jobs were in danger, and that there were not in fact less restrictive means for achieving this goal. All of these requirements were novel for the national labour law regimes.

In the Laval case, a Latvian construction company undertook work in Sweden for which it posted Latvian workers to Sweden. ${ }^{147}$ The local Swedish union began negotiations with Laval in order to set the wage rates for the Latvian workers. The Swedish industrial relations system leaves setting of wage rates to sector specific negotiations between management and labour. Laval, which had already signed a collective agreement including the setting of wages with a Latvian union, refused to sign onto the local collective agreement for the Swedish building sector. The agreement would have forced it to pay the Latvian workers rates much higher than it had planned. The Swedish union then blockaded Laval construction sites, and a secondary, sympathy boycott was undertaken by the local electricians' union. This industrial action, which was legal in Sweden up until that point, was effective, and Laval had to back out of its contracts and declare bankruptcy in Sweden.

The ECJ court decided that labour law as such was not outside the scope of Treaty provisions on free movement. Significantly, it recognized collective action as a

\footnotetext{
${ }^{144}$ Barnard, EU 'Social' Policy

${ }^{145}$ For analysis of the Laval and Viking decisions, see generally Barnard, Catherine, Viking and Laval: a Single Market Perspective in Ewing, K and Hendy, J, eds, The New Spectre Haunting Europe: The ECJ, Trade Union Rights and the British Government (Insitute of Employment Rights 2009); Kilpatrick, Claire, "Laval's Regulatory Conundrum: Collective Standard Setting and the Court's New Approach to Posted Workers" (2009) 34 Eur.L.Rev. 844; Bercusson, Brian "The Lisbon Treaty and Social Europe" (2009) 10 ERA-Forum 87. For an argument that similar cases to Laval and Viking would have been judged more favourably to collective bargaining rights see Steven, L, "Laval, Viking, and American Labour Law" (2011) 32 Comp. Lab. L. \& Pol'y J. 1079. Two more decisions of the ECJ add to this line of caselaw. Case C-346/06, Dirk Rüffert $v$ Land Niedersachsen [2008]; Case C-319/06 Commission of the European Communities v Grand Duchy of Luxembourg [2008].

${ }^{146}$ Case C-438/05 International Transport Workers' Federation, Finnish Seamen's Union v Viking Line ABP, OÜ Viking Line Eesti [2008].

${ }^{147}$ Case C-341/05 Laval un Partneri Ltd v Svenska Byggnadsarbetarefoörbundet [2008].
} 
fundamental right to be exercised in accordance with the fundamental economic freedoms recognized by the Treaties. The court found that collective action limiting free movement of services, such as the one at stake, needed to be exercised for reasons of public interest and needed to be proportional to its legitimate end. Conceding that the protection of workers was a legitimate end, the Court nonetheless found that the specific industrial action had been disproportionate.

These decisions prompted intense reactions from social progressives, particularly in Scandinavia. ${ }^{148}$ Even the European Economic and Social Committee urged the EU to strengthen its social protections at the constitutional level, advocating for a Treaty change to help balance social and economic rights. ${ }^{149}$

Ulrich Muckenberger, who was involved with the 1997 "Manifesto for Social Europe" advocating for the constitutionalization of social values, urged a "Post Laval Social Manifesto," claiming that the ECJ's balancing of social rights against civil liberties was legally incorrect. ${ }^{150}$ According to this account, the inclusion of social rights in EU law has not made much of a difference because they remain subordinated to market access rights. This typically progressive stance, however, bears some analysis as well. More specifically, it would be important to analyze the consequences of these ECJ judgments beyond the formal, legal prevalence of one right over another. ${ }^{151}$ The language of social rights and "Social Europe" is equated with the wellbeing of all workers. But the cases show that the interests of Western and Eastern European workers may not be necessarily aligned - in fact, they can be at odds with one another. This does not mean that they cannot be made compatible, for example by establishing a minimum floor of labour standards throughout Europe and avoiding capital flight to other continents. It would be necessary, though, to show how that would be pursued. Otherwise, it would seem that European workers would be better-off had the ECJ decided these cases the opposite way; this glosses over conditions for workers in Eastern Europe and the social development prospects for the new EU members.

Second, the EU has seemingly incorporated social policy in its formal response to the financial crisis. ${ }^{152}$ In response to the crisis, the EU implemented financial reform, financial stabilization, economic governance reforms, and measures to facilitate growth. ${ }^{153}$ Although securing a stable economy through economic governance reforms may help growth, this is unlikely to happen under stringent austerity measures. Because Member States do not have autonomy over their monetary policy and cannot devalue

\footnotetext{
${ }^{148}$ Woolfson, Charles, Thörnqvist, Christer and Sommers, Jeffrey, "The Swedish Model and the Future of Labour Standards After Laval" (2010) 41 Industrial Relations Journal 333-350.

${ }^{149}$ Opinion of the European Economic and Social Committee on "The Social Dimension of the Internal Market" (own-initiative opinion) C-44/91 [2011].

${ }^{150}$ Muckenberger, Ulrich 'Towards A Post-Viking/Laval Manifesto for Social Europe,' CELLS online paper series, vol 1, 4 (2011) www.law.leeds.ac.uk/assets/files/research/cells/mueckenberger.pdf (emphasis added).

${ }^{151}$ Ibid.

${ }^{152}$ For example, the EU Social Protection Committee published a report on the Social Impact of the Economic Crisis and Ongoing Fiscal Consolidation (2011).

${ }^{153}$ Barnard, Catherine, "The Financial Crisis and the Euro Plus Pact: A Labour Lawyer's Perspective" (2012) 41 Industrial Law Journal 98, 99-103.
} 
their currency, they are experiencing considerable pressure to turn to labour law deregulation and to scale back workers' protections as a strategy to address their fiscal woes. ${ }^{154}$ At the same time, the EU's 2020 strategy for growth would require significant government spending, which, given Member State's indebtedness, seems unforeseeable.

Of the EU responses, the Euro Plus Pact (EPP) ${ }^{155}$ and the Memoranda of Understanding (MoU) between the EU/IMF and countries under bailout assistance, ${ }^{156}$ have had the greatest impact on national labour laws. Both the EPP and the MoU suggested that Member States reform their labour laws to ensure competitiveness and facilitate growth. The MoU, significantly more intrusive than the EPP, conditions the receipt of financial assistance on implementing labour law reforms. ${ }^{157}$ These reforms also have a disciplining effect on other countries in crisis, because they send a message that they, too, should deregulate their labour laws. ${ }^{158}$ After an analysis of the EU's response to the financial crisis, Barnard concludes that:

Traditionally, the EU has been seen as something of a bastion against deregulation at national level, and at least this body of directives continues to provide a floor of rights. Yet, now the EU - whether through the Council formations in the context of its recommendations in the integrated guidelines or at least the heads of state or government - has become responsible for the very deregulation it resisted for many years. Longer term, the EU may be responsible for precipitating a race to the bottom. ${ }^{159}$

In the last two years, the Commission has promoted the goal of defending the "European social model" in its communications regarding the Euro crisis. ${ }^{160}$ The Economic and Social Committee also considers the European social model so unique that it should be promoted in Europe's development assistance programs to poor countries. ${ }^{161}$

However, the Lisbon Treaty's inclusion of social rights and the enthusiasm about Social Europe indeed may not have made much difference in the EU's response to the

\footnotetext{
${ }^{154}$ Ibid 98, 103.

${ }^{155}$ The EPP, agreed to in March 2011, commits signatories to consider issues of competitiveness, employment, and the sustainability of public finances, among others, under monitoring and surveillance by the European Commission. See Europan Council, "Background on the Euro Plus Pact" (2011) ec.europa.eu/europe2020/pdf/euro_plus_pact_background_december_2011_en.pdf. The EPP, is not coupled with strong sanctions. Barnard, "Financial Crisis" 108. ,The so-called "six-pack" of EU legislation on stronger fiscal surveillance now includes surveillance of several macro-economic indicators including labour costs.

${ }^{156}$ European Commission, Economic Adjustment Programme for Greece (2012), ec.europa.eu/economy_finance/publications/occasional_paper/2012/op94_en.htm; for Ireland (2011) ec.europa.eu/economy_finance/publications/occasional_paper/2011/pdf/ocp76_en.pdf; for Portugal (2011) ec.europa.eu/economy_finance/publications/occasional_paper/2011/op79_en.htm.

${ }^{157}$ Barnard, "Financial Crisis" 98.

${ }^{158}$ Ibid 112 .

${ }^{159}$ Ibid 113 .

${ }^{160}$ In fact, the Commission has proposed the safeguarding of the European social model as one of the reasons why member states should all pursue measures of fiscal consolidation. See European Commission, “Annual Growth Survey 2012” COM(2011) 815, 4.

${ }^{161}$ European Economic and Social Committee on "The Social Dimension of the Internal Market" (owninitiative opinion) $(2011 / \mathrm{C} 44 / 15)$ art 1.7.
} 
euro crisis. On this front, the character of Social Europe must be measured against the effects of the austerity measures in each nation and how their costs and benefits are distributed between societal groups and among the Member States.

As we have seen, the EU uses identity-based social justifications to pursue policies that might not qualify as progressive. Indeed, a number of progressive scholars have expressed their dissatisfaction with the direction of Social Europe in the last decade, especially considering the ECJ's labour rights rulings. ${ }^{162}$ Even progressive supporters of the EU level were disillusioned after Laval. ${ }^{163}$ It is arguable that the EU's seemingly neoliberal policies are now being pursued under the guise of "social" discourse.

What have been the limits of using identity arguments to promote a social rights strategy to advance an economic agenda? Progressives in Europe quite successfully enshrined social rights in European treaty law, and promoted a Social Europe identity. So far, however, the results seem paltry at best. For example, during the recent Euro crisis, having adopted a Social Europe model does not seem to have made much difference. This opens social rights to the familiar critique of legitimation, claiming that they are enabling economic policies by reference to their compatibility to the social model, which would otherwise look less palatable. The European experience also shows that resorting to identity and social rights may obscure the distributional effects of policies on different kinds of workers; the insistence on preserving a set of social rights might limit the imagination of alternatives that may perhaps offer greater traction.

\section{III.Labour Reform and Economic Development: Thinking About Potential Alternatives}

New possibilities might open up if one thinks about labour regulation beyond its familiar associations, particularly in the case of Mexico. I have argued that the defence of current labour regulation in the name of revolutionary achievement, cultural pride or constitutional rights should no longer be sufficient without evidence of its social and economic benefits. When progressives cling to these arguments, they, perhaps inadvertently, concede too much. They concede that labour regulation is necessarily bad for firms, markets and the country's growth prospects; they pass on an opportunity to challenge the powerful discourse of labour flexibility; and they forego a necessary diagnosis of the current problem. Thus, they surrender an invaluable opportunity to imagine alternatives. Their main strategy is resistance, and their only alternative is the defence of the mostly indefensible status quo.

\footnotetext{
${ }^{162}$ Supiot, Alain, Conclusion: Europe's Awakening, in Moreau, Marie-Ange and Ulasiuk, Iryna, eds, Before and After the Economic Crisis: What Implications for the 'European Social Model'? (Cheltenham, Edward Elgar 2011).

${ }^{163}$ Scharpf Fritz, "The Asymmetry of European Integration, Or Why The EU Cannot Be a 'Social Market Economy"” (2009) 8 Socio-Economic Review 211-250. For example, Alain Supiot, who advocated for the constitutionalization of social values, became disillusioned after Laval and its progeny. See Bercusson, Brian, Supiot, Alain et al., “A Manifesto for Social Europe” (1997) 3 European Law Journal 189-205 (earlier position); Supiot, Conclusion (later position).
} 
Proponents of labour flexibility argue that rigid restrictions and compulsory clauses in the employment contract make it harder for firms to hire and fire, which in turn translates to less job creation, lower productivity and depressed economic growth. Progressives should re-appropriate the language and aspirations of labour flexibility. This should not only mean flexibility for employers to hire and fire at will, but also for workers. Progressives could promote an agenda that makes flexibility a means to turn the workplace into a meaningful life experience for millions of workers. Repetitive and deadening activities in factories and shops, with rigid hierarchies and little or no contribution of workers in firms' productive decisions, is routine in many sectors of the Mexican economy.

Too many firms rely on rigid and outdated systems of production and management. Flexibility could be a rallying cry to reform those modes of production. It could foster innovation by prioritizing learning and experimentation so that firms resemble schools and workers are encouraged to contribute ideas. Flexibility could change the hierarchical structure of firms from a rigid, vertical structure, to a horizontal one where employees work in teams and are required to participate in projects over which they have ownership and are encouraged to develop critical thinking and collaboration. ${ }^{164}$ Flexibility could mean a workplace where competition and cooperation channel work towards a common purpose and give workers an opportunity to realize themselves. That these goals seem unpractical or even utopian in Mexico says more about the rigidity of our firms' management and systems of production than of the desirability or feasibility of these aspirations.

Flexibility should also mean labour mobility. For too long, employers forewent their ability to fire, hire, and bargain over working conditions in return for industrial peace. They obtained stability and the return on their human capital investment by ensuring workers they had trained remained in the firm for their entire productive life. Workers sacrificed their aspiration to participation in management and production decisions - or even of ownership - and their ability to withhold their labour and disrupt production. Workers were promised secure, stable jobs that paid family wages and provided benefits. This bargain worked relatively well for many years when internal labour markets where dominant and the domestic economy was substantially shielded from global competition.

No longer. If global economic and regulatory changes have fundamentally altered this bargain, progressives have an opportunity to contest these conditions and reshape the bargain. A cornerstone of the old bargain was permanent employment, sustained by a rule of just-cause dismissal. Given the new conditions of global economic competition, it makes increasingly less sense for progressives to look for security of workers at firm level in all sectors. Progressives could promote security of workers through helping them develop marketable skills - encouraging worker investment not in the firm, but in their own personal capabilities. ${ }^{165}$

In the old bargain, compensation upon unjust dismissal provided a cushion for workers to make ends meet while they re-entered the labour market. This compensation

\footnotetext{
${ }^{164}$ Unger, Roberto, Democracy Realized (London, Verso 1997).

${ }^{165}$ See eg Stone, Katerhine, From Widgets to Digits (Cambridge University Press 2004).
} 
worked as the functional equivalent of unemployment insurance. Progressives could promote the establishment of universal unemployment insurance, paid by society as a whole through the tax system. The details of the insurance and policies to encourage labour market re-entry would need to be worked out, but this would protect workers against dismissal while giving firms the flexibility they demand. Workers would be less dependent on one particular firm and instead encouraged to invest in their skills for the market in general.

Benefits, such as health care and pension funds, were a crucial aspect of the permanent employment relationship. This highlights the fact that labour regulation cannot be analyzed in a vacuum, but rather must be seen as part of a broader social bargain between capital, labour and the state, institutionalized as social security benefits. It is not surprising that workers would hang on to job security today because without a formal job they would lose accrued benefits and be deprived of social insurance. Furthermore, jobs with benefits, even in the formal economy, are increasingly hard to find. Once social insurance benefits like health insurance, pensions, childcare, workers' compensation, and affordable housing are universally available to all citizens, job security becomes considerably less important.

Portable skills without jobs are useless. These reforms would need to be paired with a concerted strategy to stimulate the economy and create jobs. Labour flexibility, as it is currently advanced, is no development strategy. Even though it is currently promoted as one of the pending structural reforms and a key that would open the door to firm's competitiveness and job creation, it is hard to see how that would happen. At best, it is a strategy to increase firms' productivity at the margins through reduction in labour costs and further precarisation of jobs. This is not a sustainable, long-term strategy for job creation, much less a strategy for economic growth.

To see why the proposal of the dominant flexibility agenda is an illusion one needs to look no further than at how the labour market operates in practice - not simply what the law in the books says, but the rules governing everyday action. There is already rampant flexibility in the labour market. Many economic sectors are already quite flexible, where the employment contract restrictions in hiring and firing are honoured in the breach and benefits are not part of the contract. This de facto labour flexibility is sometimes achieved by breach. Sometimes it is by ingeniously bypassing the law, for example, by hiring workers through a third party. Furthermore, by some estimates, half of the labour force works in the informal economy, which is as flexible as it gets. Flexibility in labour costs can also be measured by looking at the dramatic decline in real wages in Mexico. Mexico has some of the lowest real wages in Latin America. ${ }^{166}$ Since the 1990s, the productivity gains resulting from declining labour costs have mostly gone to employers.

To better diagnose the labour market, we must recognize that there are several labour law regimes that operate in the economy. Even though the applicable labour law is the same, its real hold varies. The likelihood of effective enforcement increases with the size and market relevance of firms, effective worker representation, probability of inspection

\footnotetext{
${ }^{166}$ World Bank, “2013 World Bank Development Report on Jobs” (2012) econ.worldbank.org.
} 
visits and expedited remedies by labour tribunals. Consider three different labour law regimes that I call "employee-friendly," "employer-friendly" and "free-for-all." 167

In the employee-friendly regime, the current labour law is applied at its fullest. Employees work under permanent contracts and enjoy most benefits provided by law. This regime operates in a few economic sectors like manufacturing, mining and electricity, particularly medium-size and big firms. These are the traditionally unionized sectors, where workers often have effective representation and employers have an interest in preserving their investment in workers' human capital by avoiding turnover. These are also the firms that are most visible and likely to be caught by inspectors or sued by workers if they break the law.

In the employer-friendly regime, labour restrictions are loose and benefits scarce or non-existent. Limitations on hiring and firing are bypassed by outsourcing and by employing workers as independent contractors. Labour law is vastly underenforced or subverted by legal fictions and, given low levels of worker organisation, firms enjoy de facto labour flexibility. This regime is operative in many sectors including services, tourism and food preparation, and it is most prevalent in micro, small and medium size firms.

The free-for-all regime is the informal economy, where labour law does not reach and where firms mostly operate entirely outside the regulatory framework. This is a highly flexible regime where workers and employers can bargain depending on their actual power, and can expect very little legal enforcement.

Would making the labour regulation more flexible achieve what its proponents promise? Hardly, it seems. The only sector where it could have real bite is the employeefriendly regime, because it is not flexible already. However, the potential benefits need to be analyzed. The claim that labour flexibility would create jobs and increase output assumes that the demand for labour is quite elastic. These relevant economic sectors are quite capital intensive, however, with labour costs representing a small share of the total cost of production. When the share of labour costs - such as wages and labour protections - in the firm's total costs is small, the labour demand tends to be inelastic. Under this scenario a decrease in labour costs, due to more flexible regulation, is unlikely to have a significant impact on job creation. ${ }^{168}$

Even if cheaper labour costs create jobs in these industries, these may result in the significant deterioration of wages and working conditions. Given fixed capital costs and a small share of labour in total costs, lower wages and labour benefits may not guarantee higher overall productivity. Even if we were to see an increase in productivity, past productivity increases due to lowered wages does not confirm a link between higher productivity and job creation. ${ }^{169} \mathrm{We}$ can only see this by analysing the employee-friendly

${ }^{167}$ This discussion draws partly from Santos, "Labor Flexibility" 89-97.

168. See eg Farkas, George and England, Paula, eds, Industries, Firms, And Jobs: Sociological And Economic Approaches (Aldine Transaction 1994). For empirical evidence that labour regulation's effects may be quite different between those on capital-intensive and labour-intensive industries, see Ahsan, Ahmad and Pages, Carmen, "Are All Labour Regulations Equal? Evidence from Indian Manufacturing" (2009) 37 J. Comp. Econ. 62, 71-75.

69. The physical volume of manufacturing output in Mexico increased considerably in the late twentieth 
regime with the specific sector it regulates and looking at how the law operates in reality, not by treating it in the abstract.

In the current debate, there is surprisingly little diagnosis of how labor regulation actually works and what a flexibility reform would mean for different economic sectors as well as for workers and employers in these different labor regimes. Labour regulation does not have to be the same for all sectors. Different economic sectors can have different forms of labour contracts. Labour regulation is not uniform on the books or in practice. Any labour reform should be part of a broader development strategy, taking into account the conditions of different economic sectors and the role they would play in the overall national strategy for competition and job creation.

One final, crucial element of a labour flexibility reform concerns unions and unionized workers. Unions must be able to compete with one another, and workers should be empowered to participate in the governance of their unions and to challenge their leadership. For too long, the democratic aspirations of society have been suspended in the workplace. There is no reason why democratic life and the desire to experience meaningful participation and influence in society should stop at the firm's door, where workers spend a significant part of their lives. Such a reform would require the disentanglement of the government from control over union's existence, elections and governance - much like it has happened with political parties. Similarly, an independent body could be entrusted to register unions, monitor their internal elections and ensure electoral competition between them to gain majority control over collective agreements.

If union life is to be democratic - and the unions are to be attractive again to society there should be competition over union leadership. This requires elimination of reelection or else term-limits. Furthermore, serious remedies must be available to workers to challenge their leaders when their interests have been affected. This does not mean dismantling all the elements of the collective bargaining system. Some, which enable workers to organize and help avert collective action problems, may be retained. But these rules, like the closed-shop and compulsory union fees, have been subverted for too long against the interest of workers. These mechanisms of collective bargaining would be worth preserving only if corporatist institutions can be reformed to foster independent unions and a vigorous workforce that makes leadership accountable.

\section{Conclusion}

In the current global economic conditions, labour law advocates find themselves on the defence. There are strong pressures worldwide to dismantle labour regulations and social security institutions. These regulations were introduced in the twentieth century as modern states stepped in to ensure a minimum floor of protections for workers and to

century. However, this productivity increase has not had an impact on employment levels. In the year 2000, employment levels had not recovered from 1993 levels, despite significant growth in the maquiladora industry in the same period. Lower levels of employment can be attributed to an increase in labour productivity, which grew 46.3 per cent from 1993 to 2000, massive layoffs in the non-maquiladora manufacturing sectors due to an increase in competition from imports, and dismemberment of chains of production in the domestic market. See De la Garza Toledo, Enrique Estructura Industrial y Condiciones de Trabajo en la Manufactura, in La Situación Del Trabajo En Mexico (2003) 251, 254-55. 
mediate conflict between labour and capital. Once seen as a sign of a modern and dynamic industrial economy, labour regulation is derided today as a rigid vestige of the past. The rallying cry for reform is "labour flexibility," which is associated with all things positive of the new economy and proposes to cure the ills of unemployment, lack of competitiveness, and stagnant growth.

Faced with the attack on labour regulation, advocates of social law resort to three powerful defences: identity and national pride, the historically progressive character of labour law and labour rights as constitutional or human rights. These powerful arguments may be potential antidotes to deregulatory pressures. Proffered strategically to resist labour flexibility reform, when deemed less desirable than the status quo, these arguments may have some instrumental value. I argue in this article, however, that they also have significant downsides. These arguments eschew an analysis of the consequences of existing labour regulation, and they fail to answer the flexibility critiques, even if they are unfounded. Additionally, these arguments make it harder to imagine alternative, progressive regulatory mechanisms to address workers' concerns other than hanging on to the status quo.

Analysing Mexican labour law's traditional narrative, I have challenged claims of workers' rights national originality and inherent progressiveness. I show that the emergence of workers' rights and labour legislation in Mexico was the result of a truly international phenomenon, where foreign ideas and laws played an important role. Moreover, the constitutionalization of workers' rights and subsequent labour legislation was more the result of a political compromise than the historical victory of a radical program. These challenges call for rethinking labour regulation, even to defend parts of it, by looking at its current effects rather than by invoking national myths that elude these questions, however dear these stories might be.

In the present debate, the PRI has used the social law discourse, resorting to national pride and to labour regulation's assumed progressiveness, to advance a bill that includes the flexibility recipes for employment contracts and preserves the worst aspects of corporatism in collective bargaining favouring old, official unions. This shows how malleable the social position can be and questions its association with a necessarily progressive political position.

The insights from Mexico may be relevant for other countries where social advocates use similar identity-based arguments and equate labour regulation with necessarily progressive results. In Europe, advocates have used identity-based arguments to defend social regulation, including labour law, at the regional and the national levels. Regionally, advocates have attempted to constitutionalize social rights, arguing that they should be recognized as inherent part of European identity expressed in the notion of "Social Europe." Their aim is to reshape European economic integration by introducing regional social values. Nationally, social advocates less keen on the regional project have used identity to defend domestic labour regulation and national welfare institutions against the inroads of unfettered market integration. 
To some extent, these projects might be useful in resisting labour market deregulation. But by portraying existing labour regulation as the best alternative, they obscure its negative consequences and make it harder to think of different legal arrangements. At the EU level, the project of consitutionalising social rights has been successful, resulting in new treaty language and increasingly socially-oriented EU commission discourse. However, several ECJ cases and the EU's response to the financial crisis make clear that social law is very capacious and can be co-opted by both the neoliberal market-integration project and the labour flexibility program. The constitutionalization of social rights, social advocates have painfully found out, does not necessarily lead to the results they foresaw. This highlights the political indeterminacy of social law discourse and the downsides of a strategy predicated on identity and constitutional rights.

Domestically, the retrenchment to the national welfare state as a strategy to resist the EU integration project may also lose sight of problems within the existing social model. Additionally, it narrows the view to the national arena precisely at the time when vital questions of competition and distribution, between capital and labour and between different groups of workers, involve transnational rules and actors. The critique of the supposed national or regional identity arguments in social law seeks to broaden the scope to the transnational arena, thinking about collective solutions for workers in the face of regulatory competition. By doing this comparison, I do not mean to suggest that the situation in Mexico and Europe is the same or that the critiques in the Mexican context are simply transferable. Instead, I seek to illuminate important parallels in the arguments advanced by social advocates. The insights from the Mexican analysis may be suggestive of a broader phenomenon, perhaps one of progressive originalism running up against arguments of economic necessity.

Using the Mexican case, I suggest that there is an opportunity to engage with the deregulatory agenda for labour flexibility in a more productive way. First, we need a more comprehensive diagnosis of how labour regulation takes hold in different economic sectors. I argue that there are at least three different regimes in operation, ranging from formality and effective enforcement, to loose enforcement to informality. By considering the relationship between these labour regimes and economic sectors, we can better imagine what the results of potential labour reform would be.

In my view pro-labour advocates could challenge the assumptions of labour flexibility without needing to hang on to existing labour market regulation. They could appropriate the aspirations of flexibility to benefit workers, demanding more ambitious reforms that address firms' outdated modes of production and management to create a more participatory and meaningful workplace. At the same time, pro-labour advocates can propose ending the dependency on permanent employment for basic entitlements such as health, childcare and retirement funds, moving toward a universal coverage system. This debate could be an opportunity to rethink legal mechanisms that empower workers under conditions of global economic competition, and to do it while being mindful of the effects on the country's development prospects. 